
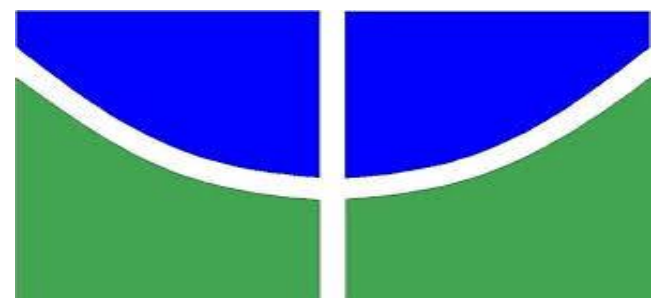

UNIVERSIDADE DE BRASÍLIA

FACULDADE DE EDUCAÇÃO FÍSICA

PROGRAMA DE PÓS-GRADUAÇÃO STRICTO-SENSU EM EDUCAÇÃO FÍSICA (DISSERTAÇÃO)

\title{
DE ANTENA LIGADA NA "ATENAS BRASILEIRA": UM ESTUDO DE RECEPÇÃO MIDIÁTICA EM TORNO DA COPA DO MUNDO DE 2014 SOB OLHARES DE JOVENS ESCOLARES EM SÃO LUÍS - MA
}

Ywry Crystiano da Silva Magalhães

BRASÍLIA - DF 


\section{DE ANTENA LIGADA NA “ATENAS BRASILEIRA": UM ESTUDO DE RECEPÇÃO MIDIÁTICA EM TORNO DA COPA DO MUNDO DE 2014 SOB OLHARES DE JOVENS ESCOLARES EM SÃO LUÍS - MA}

YWRY CRYSTIANO DA SILVA MAGALHÃES

Dissertação apresentada ao programa de Pós-Graduação em Educação Física, da Universidade de Brasília, como requisito para o título de Mestre em Educação Física do candidato.

ORIENTADOR: Dr. ALFREDO FERES NETO 
Ficha catalográfica elaborada automaticamente, com os dados fornecidos pelo(a) autor(a)

M515a

MAGALHÃES, YWRY CRYSTIANO DA SILVA MAGALHÃES

DE ANTENA LIGADA " NA ATENAS NBRASILEIRA": UM ESTUDO DE RECEPÇÃO MIDIÁTICA EM TORNO DA COPA DO MUNDO DE 2014 SOB OLHARES DE JOVENS ESCOLARES EM SÃO LUÍS - MA / YWRY CRYSTIANO DA SILVA MAGALHÃES MAGALHÃES; orientador ALFREDO FERES NETO FERES. Brasilia, 2015.

$120 \mathrm{p}$.

Dissertação (Mestrado - Mestrado em Educação Física) - Universidade de Brasilia, 2015.

1. EDUCAÇÃO F́́́SICA. 2. FUTEBOL. 3. RECEPÇÃO MIDIÁTICA. 4. DISCURSOS . 5. MÍDIA. I. FERES, ALFREDO FERES NETO, orient. II. Título. 


\section{AGRADECIMENTO}

A Deus por ter me dado vida e sabedoria para que eu pudesse concretizar mais um momento que tanto sonhei.

A toda minha família pelo carinho de sempre.

Ao Grupo de Estudos e Pesquisas Pedagógicas em Educação Física GEPPEF- pelos ensinamentos.

A todos os professores do Curso de pós-graduação em Educação Física da UnB, em especial ao professor Alfredo Feres Neto pela confiança depositada em mim.

Dedico este trabalho a Maria Luísa e Ywry Filho. 


\section{SUMÁRIO}

RESUMO

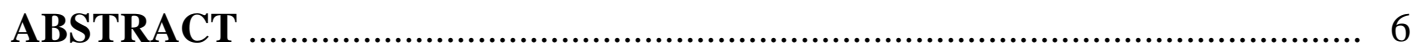

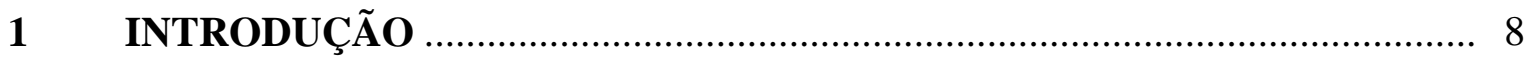

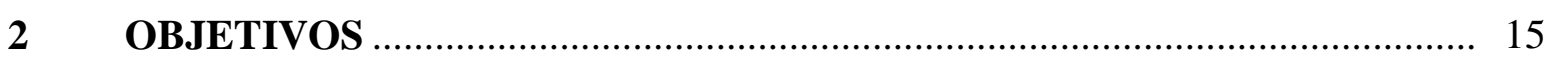

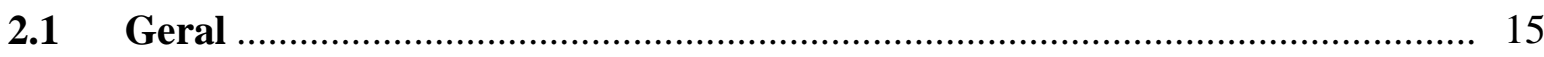

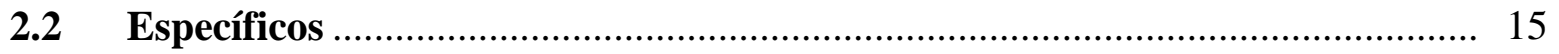

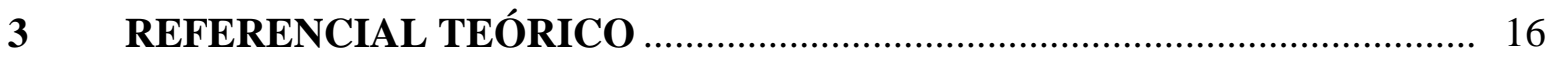

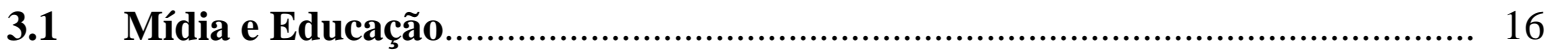

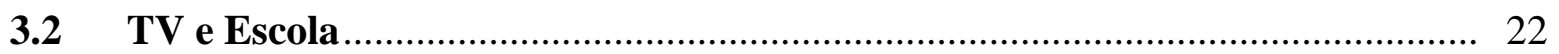

3.3 Mídia e Educação Física ......................................................................... 26

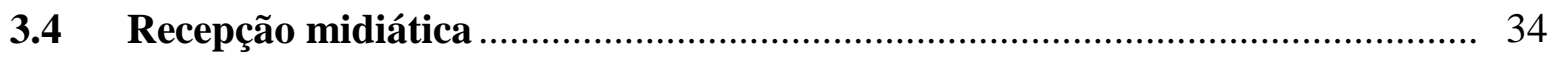

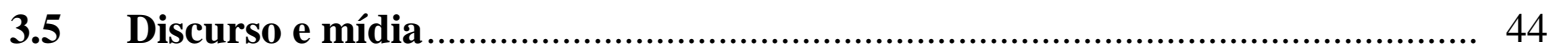

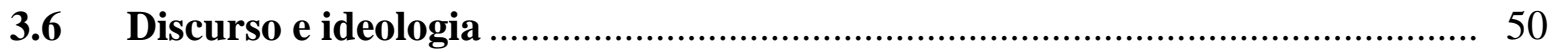

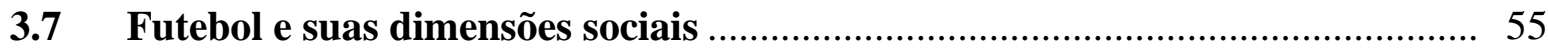

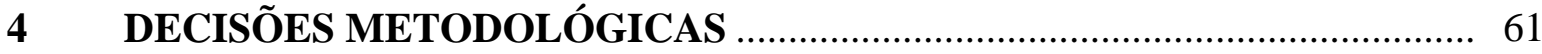

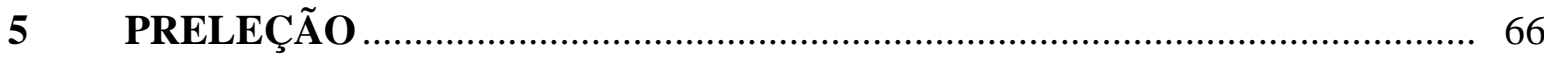

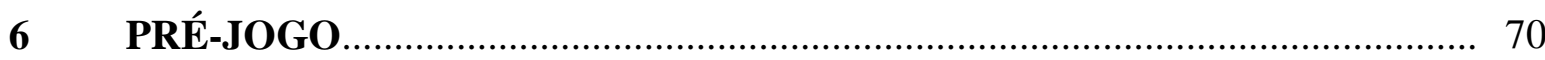

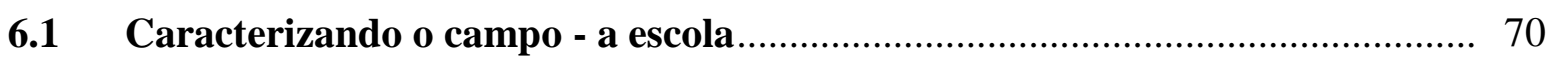

6.2 Caracterizando o campo - os professores de Educação Física........................ 71

6.3 Caracterizando o campo - os alunos pesquisados …..................................... 73

$7 \quad$ O JOGO

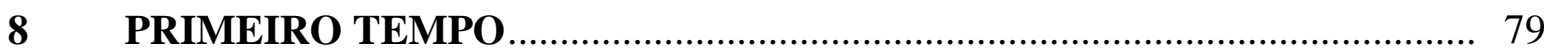

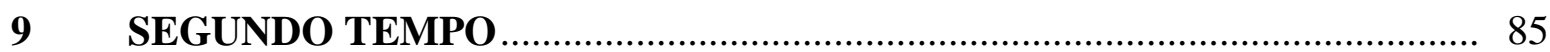

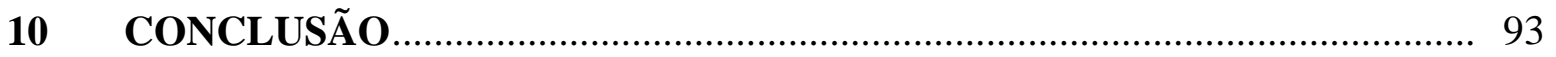

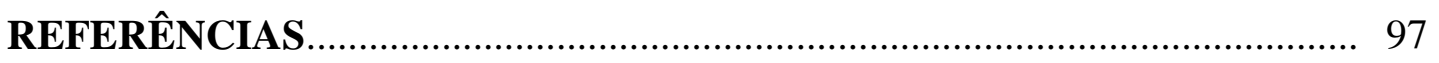

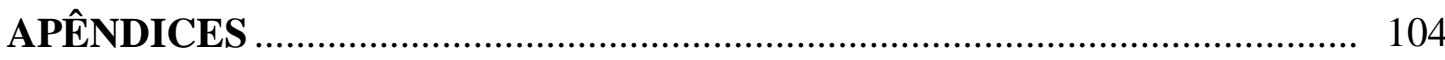




\title{
RESUMO
}

\section{DE ANTENA LIGADA NA “ATENAS BRASILEIRA": UM ESTUDO DE RECEPÇÃO MIDIÁTICA EM TORNO DA COPA DO MUNDO DE 2014 SOB OLHARES DE JOVENS ESCOLARES EM SÃO LUÍS - MA}

\author{
Autor: YWRY CRYSTIANO DA SILVA MAGALHÃES
}

Orientador: Dr. ALFREDO FERES NETO

Este trabalho teve como objetivo analisar a recepção midiática dos discursos televisivos em torno do futebol por meio dos procedimentos discursivos e interdiscursivos. Tomando as mídias como tema de reflexão e análise é possível observar que além de estarem presentes em nosso dia a dia, elas se constituem em um assunto de interesse geral, e lógico, a Educação Física não poderia ficar alheia a essas discussões. Dessa maneira, a indústria do entretenimento utiliza a televisão para incentivar o consumo de bens e serviços, nessa lógica surgem os elementos da cultura corporal como objetos a serem também comercializados na forma de esporte, ou seja, as manifestações da cultura corporal e o objetivo da Educação Física de tratar pedagogicamente dessas manifestações, estão cada vez mais, sendo subsumidas pela hegemonia do esporte. E o futebol é o maior representante dessa hegemonia, uma vez que é amplamente praticado no contexto escolar, mas os sentidos atribuídos a sua prática estão restritos à 
racionalidade instrumental, limitando significativamente o seu valor pedagógico e, portanto, às possibilidades de contribuir com a formação dos sujeitos. Para que os sujeitos não assumam, de maneira inconsciente, os valores, sentidos e significados veiculados por meio dessa influência televisiva, é necessário o recurso das mediações que oportunizem uma leitura mais crítica desses discursos e que promovam, nos sujeitos, autonomia para a realização de suas escolhas. Nesse sentido, em nosso estudo utilizamos um quadro teórico composto pelos conceitos da Teoria da Análise do Discurso articulados aos estudos de Recepção e da Teoria das Múltiplas Mediações, sob o viés dos Estudos Latino-Americanos. O trabalho de campo foi realizado na Escola Cintra em São Luís - MA, numa turma de $1^{\circ}$ ano do ensino médio. Para conhecermos suas principais mediações e o tratamento dados as mensagens que consomem por meio do discurso televisivo acerca do futebol na Copa do Mundo de 2014 foram mobilizados como procedimentos, instrumentos e técnicas de pesquisa: questionário, grupos focais e observação participante. Concluímos que a Educação Física deve buscar novas metodologias de ensino para que os alunos possam compreender a temática estudada na sua totalidade e também inserir nos seus estudos temas relacionados ao cotidiano como os eventos esportivos e suas relações com a mídia para entendermos os seus impactos na sociedade.

Palavra Chave: Mídia. Recepção midiática. Futebol. Discursos. 


\begin{abstract}
This study aimed to analyze the media reception of television speeches around football through the discursive and interdiscursive procedures. Taking the media as the subject of reflection and analysis you can see that in addition to being present in our daily lives, they constitute a subject of general interest, and logical, physical education could not remain aloof to these discussions. In this way, the entertainment industry uses television to encourage the consumption of goods and services, this logic come the elements of body culture as objects to be also marketed in the form of sport, ie the manifestations of physical culture and the goal of Physical Education to treat pedagogically these manifestations, are increasingly being subsumed by the hegemony of the sport. And football is the most representative of this hegemony, as it is widely practiced in the school context, but the meanings attributed to their practice are restricted to the instrumental rationality, significantly limiting their educational value and therefore the possibilities of contributing to the training of subjects. So that the subjects did not take, unconsciously, values, senses and meanings conveyed by this television influence, it is necessary the use of mediations that oportunizem a more critical reading of these speeches and to promote, in subjects autonomy to carry out your choices. Accordingly, in our study we used a theoretical framework composed of the concepts of the theory of discourse analysis articulated the Reception studies and the Theory of Multiple Mediations under
\end{abstract}


the bias of Latin American Studies. Fieldwork was conducted at the School Cintra in Sao Luis - MA, a 1st year high school class. To know their main mediations and treatment data messages that consume through televised speech about the football World Cup in 2014 were mobilized as procedures, instruments and research techniques: survey, focus groups and participant observation. We conclude that physical education must seek new teaching methods for students to understand the subject studied in its entirety and also enter in their studies issues related to daily life such as sports events and their relations with the media to understand their impacts on society.

Keyword: Media. Media reception. Soccer. Speeches. 


\section{INTRODUÇÃO}

As práticas pedagógicas da Educação Física vêm se constituindo para professores e pesquisadores da área num amplo campo de estudos e reflexões, tanto no que se refere às abordagens das aulas, avaliação do processo ensinoaprendizagem e organização dos conteúdos.

Sobre abordagens, no campo da Educação Física podem ser definidas como movimentos engajados na renovação teórico-prático com o objetivo de estruturação do campo de conhecimentos que são específicos da área. Tanto que, Souza Júnior (1999) afirma que estes movimentos surgem na busca de reestruturar os conteúdos, a metodologia das aulas e a forma de avaliar da Educação Física.

Neste trabalho utilizaremos predominantemente a abordagem de caráter crítico emancipador, pois de acordo com Betti (1998) a entendemos como uma reflexão pedagógica que desempenha um papel político-pedagógico que encaminha propostas de compreensão e possibilita reflexões sobre a realidade da cultura corporal de movimento.

Sobre cultura corporal de movimento, entendemos como Todas as formas de manifestações, de expressão corporal, são historicamente criadas e culturalmente desenvolvidas. Porém, isso não nos impede de em alguns momentos dialogar com autores que defendem outras formas de pensar a Educação Física.

No que tange à metodologia das aulas, alguns pesquisadores Betti (1998); Pires (2000) e Bracht (2000) apontam para uma metodologia crítica que se relacione com o cotidiano dos alunos, que torne as aulas mais prazerosas, 
tornando assim o aprendizado mais significativo. Para isso, estes autores utilizam elementos midiáticos como ponto de partida para discussões das grandes transformações ocorridas na sociedade que refletiram na escola.

Tomando as mídias como tema de reflexão e análise é possível observar que além de estarem presentes em nosso cotidiano, elas se constituem em um assunto de interesse geral, e lógico, a Educação Física não poderia ficar alheia a essas discussões.

Assim, modificações sociais vão acontecendo, pelo fato das mídias também conseguirem atingir todas as classes sociais, por meio dos jornais, rádio, internet e, principalmente a televisão, que é a mídia mais consumida pela sociedade brasileira, capaz de fazer interpretações da realidade, sendo o meio mais eficaz de divulgar uma mensagem ao maior número possível de pessoas, pois

[...] a televisão brasileira chega a quase todos os lares, sendo poucas as regiões do país sem acesso a ela. Portanto, se a televisão tem essa difusão, percebe-se que é impossível compreender a sociedade brasileira sem compreender este veículo. (FADUL, 2013, p.58).

Neste sentido, utilizaremos em nosso trabalho o conceito de mídias e não de mídia, pois conforme Santaella (1992), a indústria midiática apresenta vários veículos de comunicação e cada um deles tem uma função específica que é negociada por meio das interações com o seu receptor - o que a autora denomina de cultura das mídias.

Dessa maneira, a indústria do entretenimento utiliza a televisão para incentivar o consumo de bens e serviços, nessa lógica surgem os elementos da cultura corporal como objetos a serem também comercializados na forma de esporte, ou seja, as manifestações da cultura corporal e o objetivo da Educação Física de tratar pedagogicamente dessas manifestações, estão cada vez mais, 
sendo subsumidas pela hegemonia do esporte. E o futebol é o maior representante dessa hegemonia, uma vez que é amplamente praticado no contexto escolar, mas os sentidos atribuídos a sua prática estão restritos à racionalidade instrumental, limitando significativamente o seu valor pedagógico e, portanto, às possibilidades de contribuir com a formação dos sujeitos (BRACHT, 2000).

A indústria do futebol utiliza o discurso televisivo para legitimar este esporte na escola. Não são raras as manchetes midiáticas despertando nas crianças, nos adolescentes e jovens o fascínio pelo futebol, e todas essas expectativas são levadas para a aula de Educação Física. Esse discurso é intensificado ainda mais em tempos de mega eventos esportivos (Copa do Mundo de Futebol 2014 e Olimpíadas 2016). Desse modo, frequentemente, o que se ouve e se lê a partir da mídia é que o Brasil é um celeiro de craques, despertando ainda mais o fascínio pelo futebol e isso influencia diretamente nas aulas de Educação Física, ou seja, o discurso midiático, na verdade, pretende incentivar a massificação da prática esportiva a partir do ambiente escolar, e não propriamente a qualificação da disciplina pedagógica (MASCARENHAS et al., 2011).

A mídia cria a imagem do atleta da moda para anunciar de que o mesmo é invencível, uma espécie de herói nacional, utilizado na propaganda para exacerbar o consumismo. A fascinação é tão visível que consegue transformar todo esse fenômeno em prestígio e lucro. (BETTI, 2001). Essa criação de ilusão no discurso televisivo "[...] é um recurso muito utilizado pela mídia como uma construção que permite ao leitor formas simbólicas de representação de realidade concreta". (GREGOLIN, 2001, p.25) 
Para falarmos em discurso, precisamos considerar os elementos que têm existência no social, nas ideologias e na História. Com isso, podemos afirmar que os discursos não são fixos, estão sempre se movendo e sofrem mutações, acompanham as transformações sociais e políticas de toda natureza que integra a vida humana.

A concepção francesa de Análise do Discurso afirma que o discurso é articulação do linguístico com o social, tendo como seu papel principal a materialização do processo enunciativo. Dessa forma, “[...] a linguagem passa a ser um fenômeno que deve ser estudado não só em relação ao seu sistema interno, enquanto formação linguística, mas também enquanto formação ideológica” (BRANDÃO, 1998, p.17).

Através do discurso, as ideologias podem se perpetuar, sofrer transformações, podendo ainda surgir novas formações ideológicas concomitantes ao aparecimento de novos grupos sociais, de novas formações discursivas. Nesse sentido, aparece o conceito de interdiscurso, ou seja, todo discurso só produz sentido a partir de outros sentidos já cristalizados na sociedade, verifica-se, portanto, que uma sociedade, tomada de maneira genérica, é mesclada por diferentes ideologias próprias aos diferentes discursos socialmente produzidos. Essas ideologias utilizam diversas formas de persuadir a sociedade através de veículos midiáticos apresentando o dito e não dito, em outras palavras, "[...] a ideologia se materializa nos atos concretos, assumindo com essa adjetivação um caráter moldador das ações" (BRANDÃO, 1998, p. 23).

Sendo assim, em meio ao crescente debate conceitual e metodológico que a Educação Física vem estabelecendo com a mídia, surge também uma preocupação na área em promover interlocuções pedagógicas que tratem 
especificamente dessa temática no âmbito escolar. Isso porque conforme indica um recente levantamento das produções acadêmicas em Educação Física e mídia realizado por Pires (2006), essa temática ainda é carente no que diz respeito aos relatos de experiências escolares.

Aprofundar essa temática da recepção midiática é desviar o olhar para o receptor numa postura de protagonista, pois ao relacionar as informações com a sua cultura em volta, acaba por construir novos sentidos a sua realidade. O tema da recepção mediática na verdade se transforma ao assumir como seu objeto o espaço de mediações que se dá na experiência das práticas culturais, individuais e coletivas, espaço de relacionamento onde se concretiza a comunicação como vinculação social. (SODRÉ, 1997).

Portanto, utilizaremos a teoria da recepção midiática de Martin-Barbero (1997), ele entende que a recepção midiática nunca é passiva, pois os sujeitos receptores são detentores de uma cultura e esta interage com a informação que é veiculada em uma espécie de negociação entre diferentes lógicas culturais.

Conforme o exposto, dado o alcance e o poder simbólico exercido pela mídia sobre os múltiplos espaços culturais, sua influência cultural não pode ser ignorada tampouco menosprezada, mesmo que muitos não atentem às ideologias conservadoras por ela produzidas e reproduzidas.

O texto midiático, que é produto de relações de contradição, de submissão ou usurpação de outros textos, só produz sentido ao ser recebido por um interlocutor- sujeito que reinterpreta o discurso do outro a partir de seu próprio discurso (AUTHIER-RVUZ, 1990).

Nesse âmbito, a escola surge como espaço propício para que se estabeleça uma reflexão sobre esse processo, e a aula de Educação Física, com tempo 
curricular adequado para a reflexão crítica e pedagógica acerca do repertório de informações, visão de mundo e concepções que dizem respeito ao fenômeno esportivo.

Dessa forma, nos debruçaremos sobre o discurso televisivo, pois esta mídia veicula com intensidade os elementos da cultura corporal de movimento que, de certa forma, pode influenciar diretamente nas práticas corporais dos alunos, seja dentro ou fora da escola.

Neste sentido, entendemos a necessidade de refletirmos sobre o discurso midiático esportivo, mais especificamente o discurso sobre o futebol, por acreditarmos que estudar qualquer elemento da cultura corporal de movimento sem considerar a perspectiva de que todas as esferas das sociedades contemporâneas possuem, em maior ou menor grau alguma relação de ordem econômica, política, social e cultural com a indústria midiática, é desconsiderar parte de um universo no qual todos nós estamos inseridos.

Para tal, é necessário (re) definir o que se entende por prática em Educação Física, ampliar o significado e alcance da expressão "prática pedagógica", repensando o que ensinar e como ensinar para então posicionarmos criticamente sobre os conhecimentos da cultura corporal.

Destacamos aqui que não pretendemos reduzir ou eliminar a rica especificidade da Educação Física, o que pretendemos é refletir, pesquisar, intervir e se posicionar diante do atual cenário social. Sendo assim, é que lançamos mão de observações sistemáticas feitas no referido cotidiano, buscando ir além daquilo que é mais visível, na verdade, a intenção é "descortinar" discursos e falas, interpretar significados, enfim, filtrar o dito e o não dito pelos atores sociais no que se refere ao futebol nas aulas de Educação Física. Sendo 
assim, lançamos mão da seguinte pergunta: Como se dá a recepção ao discurso midiático acerca do futebol, por parte dos jovens escolares? 


\section{OBJETIVOS}

\subsection{Geral}

Analisar a recepção midiática dos discursos televisivos em torno do futebol por meio dos procedimentos discursivos e interdiscursivos.

\subsection{Específicos}

a) Analisar as repercussões dos discursos dos alunos acerca do futebol;

b) Analisar nos discursos televisivos os elementos estruturantes de ordem política, econômica e social que norteiam a prática do futebol. 


\section{REFERENCIAL TEÓRICO}

\subsection{Mídia e Educação}

Neste primeiro capítulo iremos trazer algumas considerações sobre a relação mídia e escola à luz dos teóricos que se debruçam pela temática. Nesse sentido, não é objetivo do trabalho formular receitas prontas e acabadas sobre de como se portar diante da influência midiática no cenário educacional, longe disso, o que pretendemos é revelar possibilidades a partir de experiências concretas que ultrapasse os limites do "ainda não" e que nos alimente a esperança do "não mais" fecharmos os olhos diante do rico e fértil campo das mídias em nossa sociedade. Problematizar as mídias é descortinar um cenário que nem sempre leva ao público o olhar crítico sobre as intenções dos meios de informação, e também buscar nesses meios, formas aliadas para o desenvolvimento dos nossos alunos.

Ao tratar a educação escolar, não podemos perder o foco a constante reflexão sobre o seu objetivo social e histórico. Tomando como ponto de partida a inserção cada vez mais forte da mídia no seio da sociedade, entendemos que é necessário problematizá-la no ambiente escolar para que tenhamos respostas que irão sustentar a nossa prática. Refletir sobre as mídias a partir do ponto de vista da educação é entendê-la enquanto produtora de signos e significados que nos ajudam a nossa constituição enquanto sujeito da nossa história. Neste sentido, o nosso estudo se propõe compreender a mídia e sua importância no processo de socialização. 
O fenômeno das mídias faz parte cada vez mais do cotidiano de crianças e adolescentes, dessa maneira, a escola não pode se furtar desse debate, oferecendo instrumentos para que o seu alunado possa entender como se usa as linguagens midiáticas, assumindo um papel de cidadania ativa na sociedade. Este é um dos motivos que tem mobilizado a escola a se debruçar sobre os meios midiáticos e de formar expectadores ou mesmo leitores críticos dos meios de comunicação massa. Sobre comunicação de massa, Setton (2011) entende como meios tecnológicos, eletrônicos e digitais que propiciam a mediação entre a mensagem e o receptor, ou seja, são veículos responsáveis pela transmissão e difusão de alguma expressão cultural.

Não é por acaso ou mero modismo que muito tem se falado da necessidade da escola voltar-se para a análise das mídias. As evidências levantadas por diferentes autores Setton (2011); Belloni (2007) e Orofino (2005) são enfáticas na constatação de que os veículos de comunicação de massa participam em grande escala da formação das gerações atuais. Isto porque, é fato, que as horas dispensadas a tais veículos, seja intencionalmente ou não, ocupam grande parte, se não, a maior parte, do tempo presente. Não se trata apenas do tempo de exposição a esses veículos, visto que este é um argumento vastamente utilizado, como se quanto mais expostos os seres humanos estivessem às mensagens midiáticas mais contaminados, ou alienados estariam. Trata-se também da intensidade com que tais mensagens passam a ocupar a gerência da vida cotidiana, ou seja, o grau de veracidade e adesão que tais discursos assumem como base para as discussões, opiniões, valores e crenças das quais a sociedade se nutre, além das formas de ser e agir com as quais os homens têm dialogado com o mundo. 
Sendo assim, as reflexões sobre o papel das mídias nas sociedades contemporâneas e suas relações com a educação de crianças, jovens e também de adultos, não é um campo de investigação novo (OROFINO, 2005). A questão da tecnologia educacional de orientação funcionalista é tão antiga quanto à própria emergência dos meios de comunicação em nossas sociedades. Segundo Orofino (2005) desde as primeiras décadas do século XX, há iniciativas de educação pelo correio, via mídia impressa e também pelo rádio, o que remonta ao início dos debates sobre o uso das mídias para fins instrucionais. Mas não é esta perspectiva que vamos seguir. O que pretendemos aqui é trazer uma discussão sobre mídia/educação que seja compreendida enquanto campo de conhecimento cujo espaço seja o da teoria crítica. E neste sentido, a história no Brasil é mais recente. Morán (apud OROFINO, 2005) realizou um histórico sobre diferentes propostas em nosso país e localizou, no início nos anos 60, o projeto Leitura Crítico dos Meios de Comunicação realizado pela UCBC (União Cristã Brasileira de Comunicação) como uma das pioneiras no campo. A partir daí diferentes iniciativas emergiram com base em projetos desenvolvidos em outros países e ampliaram o conjunto do pensamento crítico sobre o tema. Dentre os quais destacamos a pedagogia da linguagem total, sugerida por Francisco Gutierrez e que já nos anos 70 propunha que a escola utilizasse diferentes linguagens em seu cotidiano; a educação para a mídia, bastante difundida no Brasil por Maria Luíza Belloni (2007) que propõe a leitura ideológica dos textos midiáticos; a educomunicação, que atualmente vem sendo desenvolvido no Brasil sob orientação dos professores Osmar de Oliveira Soares e Adilson Citelli (ECA/USP) e que propõem uma nova reflexão epistemológica sobre o campo com ênfase nos processos de produção midiática na escola.

Nesta ótica, as mídias são partes essenciais dos processos de socialização das novas gerações, mas não apenas, pois deve incluir também populações 
adultas, numa concepção de educação ao longo da vida. Trata-se de um elemento essencial dos processos de produção, reprodução e transmissão da cultura, pois as mídias fazem parte da cultura contemporânea e nela desempenham papéis cada vez mais importantes, sua apropriação crítica e criativa, sendo, pois, imprescindível para o exercício da cidadania. Também, é preciso ressaltar, que as mídias são importantes e sofisticados dispositivos técnicos de comunicação que atuam em muitas esferas da vida social, não apenas com funções efetivas de controle social (político, ideológico...), mas também gerando novos modos de perceber a realidade, de aprender, de produzir e difundir conhecimentos e informações (BELLONI, 2007, p.33).

Por mídia-educação convém entender o estudo, o ensino e a
aprendizagem dos meios modernos de comunicação e expressão,
considerado como parte de um campo específico e autônomo de
conhecimentos, na teoria e na prática pedagógicas, o que é diferente de
sua utilização como auxiliar para o ensino e a aprendizagem em outros
campos do conhecimento, tais como a matemática, a ciência e a
geografia.

Nesta primeira definição vemos claramente a distinção das duas dimensões da mídia-educação e a ênfase exclusiva em sua dimensão de objeto de estudo, isto é, de leitura crítica das mensagens midiáticas, ou seja, o foco, porém, não é o uso pedagógico ou didático das mídias, mas as experiências midiáticas dos jovens fora da escola para, a partir delas, ensinar sobre as mídias. Neste cenário, as mídias passam a ser um campo de estudo que têm como objetivo a produção de cultura que chega até a sociedade pela mediação de tecnologias.

Sendo assim, a mídia-educação aparece como uma proposta pedagógica de tematização da mídia no âmbito escolar com objetivo de formar cidadãos críticos e autônomos em relação à mídia. Trata-se, portanto, da busca por uma escola que dialogue com a cultura midiática e audiovisual para além das estratégias de mera aquisição tecnológica. A mídia-educação aqui enfatiza que a leitura crítica da 
mídia tem como função desmistificar as estruturas de produção dos discursos com base no reconhecimento dos traços da cultura hegemônica. Fortalece-se, portanto, a dimensão política atribuída à mídia-educação.

Considerar as diversas dimensões da mídia educação numa perspectiva integrada pode apontar na superação das contradições entre uma concepção mais instrumental (educar com as mídias) e outra mais conteudística (educar sobre as mídias), que promovendo um uso crítico sobre as mensagens, favorece habilidades próprias de um indivíduo autônomo. (FANTIN, 2006, p.52).

Fantin (2006), aponta que a Mídia-Educação possui três perspectivas: instrumental, crítica e produtiva. A perspectiva instrumental vincula-se a ideia de educação com os meios, uma estratégia didático-metodológica para utilizar as mídias como ferramenta, um recurso. Por outro lado a perspectiva crítica visa à educação sobre os meios, uma tentativa de compreender os signos, sentidos e significados, a ideologia das mensagens. Por fim perspectiva produtiva relaciona-se com a educação através dos meios, a mídia é uma linguagem para veicular o conhecimento produzido.

Sendo assim, além do sujeito ser formado com os recursos tecnológicos das mídias, nessa perspectiva visa-se um sujeito que seja crítico e reflexivo, compreendendo como se dão os processos midiáticos; também deve ser capaz de formar cidadãos produtores de mídia, ainda mais se consideramos as possibilidades das TICs, em especial a internet. Formar um receptor sujeito implica na formação de cidadãos críticos reflexivos sobre a mídia e as informações nela veiculadas, no sentido de superar a dicotomia entre apocalípticos e integrados, denunciada por Eco (1993).

Para Eco (1993) os apocalípticos, pensam a mídia como uma forma alienação, portanto valorizam os aspectos negativos do fenômeno midiáticos; Já os integrados vêem nos elementos midiáticos possibilidades para a emancipação 
do pensamento crítico, ou seja, viam nas mídias elementos de integração da cultura que serviria para a democratização do acesso as informações.

Os textos midiáticos geralmente combinam várias linguagens ou formas de comunicação - imagens visuais ( paradas ou em movimento), áudio (som, música ou discurso) e a linguagem escrita. A mídia-educação busca portanto o desenvolvimento de uma ampla competência, não apenas em relação à mídia impressa, mas também nestes outros sistemas simbólicos de imagens e sons. Esta competência é freqüentemente descrita como uma forma de alfabetização; e se defende hoje que, no mundo moderno, a alfabetização em mídia é apenas tão importante para os jovens quanto é a alfabetização tradicional em texto impresso. (BUCKINGHAM, 1993, p.4)

Sendo assim, tomando as mídias como tema de reflexão e análise é possível destacar que são temas/elementos de discussão do cotidiano, ou seja, são pautas, que interessam a sociedade e atuam como agentes sociais no processo de educação, pois funcionam como instâncias que transmitem valores, padrões e normas de comportamentos.

Neste contexto é que Kellner (2001) vai apresentar a idéia de que a mídia opera numa perspectiva de "pedagógica cultural". O autor afirma que os veículos de massa, no contexto atual, “[...] contribuem para nos ensinar como nos comportar e o que pensar e sentir, em que acreditar, o que temer e desejar - e o que não". (KELLNER, 2001. p.10).

Sendo assim, não só a escola, a família, as religiões, entre outras instituições estão presentes na educação contemporânea, mas, em especial, as mídias representam uma parcela significativa de tudo o que é partilhado enquanto cultura no cenário presente. É evidente, assim, que a cultura transmitida via mídia constitui e é constituída pelo tecido social, impregnando-se especialmente no campo educativo. 
Neste caso, sendo a mídia ao mesmo tempo expressão capitalista e forma de pedagogia cultural, é mais do que de necessário a contextualização deste cenário pela educação escolar, instituição com legitimidade social para a formação crítica e emancipatória da cidadania. Caso contrário, a pedagogia cultural exercida pela mídia continuará com seus sedutores conteúdos culturais a modelar a demanda dos consumidores e a produção de pseudo-necessidades reforçadoras de valores consumistas.

\subsection{TV e Escola}

Estruturaremos esse capítulo de forma a refletir sobre o fenômeno midático - TV - e sua articulação com a escola, para então discutirmos sobre suas possibilidades como fonte de aprendizado no processo educacional. Neste sentido, adotaremos uma posição otimista acerca da TV, sem perder de vista o rigor crítico diante de algumas situações para que não façamos análise de punho aparente. Dessa forma esperamos contribuir através de uma proposta de metodologia que elimine os equívocos e até mesmo o comodismo que circundam o binômio TV e escola.

A TV por ser um fenômeno constitutivo das sociedades contemporâneas que tem sua estrutura complexa, ambígua e muitas vezes contraditória, que oscila entre sonho e realidade, informação e manipulação torna-se um elemento midiático que necessita ser mediado e a escola como espaço pedagógico deve exercer tal função para que seus alunos possam entendê-la e sobretudo criticá-la.

Aqui nesse trabalho elegemos como mídia a ser explorada - a TV entendendo-a como espaço de interação social, de ressignificação de práticas 
dentro e fora do ambiente escolar. Conforme Napolitano (2007), a tarefa primordial do uso da televisão como objeto de estudo, é de pensar o grau de midiabilidade das suas diversas clientelas e dos indivíduos e dos grupos sociais envolvidos no seu contexto, bem como as diversas formas de recepção dos conteúdos veiculados pela mídia. $\mathrm{O}$ autor entende como midiabilidade o campo social dominado pela mídia, sobretudo a mídia eletrônica, catalisando um conjunto de experiências e identidades sociais.

A criança chega à adolescência depois de ter assistido 15 mil horas de
televisão e mais de 350 mil comerciais, contra menos de 11 mil horas
de escola. A televisão é agradável, não requer esforço e seu ritmo é
alucinante. É sua primeira escola. Quando chega aos bancos escolares,
já está acostumado a esta linguagem ágil e sedutora. E a escola não
consegue chegar perto dessa forma de contar. A criança julga-a a partir
do aprendizado na televisão. (MORÁN, 1993, p.61)

Segundo Belloni (2007) nos países em desenvolvimento, caracterizados por profundos contrastes sociais, o acesso aos objetos técnicos é também marcado pela desigualdade, tanto regional quanto social. Nestes países, a técnica tende a acentuar ainda as desigualdades de oportunidades entre as elites e as populações desfavorecidas. As técnicas de comunicação, entre as quais se destaca a televisão, não escapam a esta regra. No Brasil a TV funciona como uma espécie de escola paralela freqüentada pela quase totalidade dos jovens de várias idades e todas as classes sociais, e muitas vezes ela representa a única escola para aqueles milhões de jovens não - escolarizados.

Ainda conforme Belloni (2007), nas sociedades atuais, a TV desempenha um papel muito importante na dimensão semântica do processo de socialização, fornecendo as significações e preenchendo o universo simbólico dos espectadores, e estes, utilizam essa mídia como meio para se sentir informados no que acontece na sociedade. Portanto, cabe à escola difundir constantes discussões sobre tal realidade, transformando o espectador passivo ao espectador 
ativo, levando o aluno a compreender o sentido explícito e implícito das informações onde efetuará uma reflexão crítica sobre os conteúdos midiáticos.

Ferrés (1994) propõe que a escola eduque para o meio e com o meio, oferecendo recursos para análise crítica dos programas, incorporando audiovisual à sala de aula otimizando o processo de ensino-aprendizagem. Nessa perspectiva afirma Freire (2005, p.139) "Como educadores e educadoras progressistas não apenas não podemos desconhecer a televisão, mas devemos usá-la, sobretudo, discuti-la". Conforme ressalta Valério Fuenzallida (1999, p.43):

Diante, portanto, desta polidiscursividade da TV, o telespectador não desenvolve uma relação homogênea e unívoca, mas sim diversificada, com expectativas e gostos diferenciados. Não deveríamos portanto falar da relação com a TV, mas múltiplas relações côa a TV".

Sendo assim, os telespectadoras estabelecem preferências distintas diante do conjunto discursivo oferecido por este meio de comunicação. O consumo não é passivo; pelo contrário, ele é seletivo. E isto acontece em função das mediações culturais que se estabelecem a partir de múltiplas dimensões que constituem a própria experiência do sujeito na vida social. Por isso a TV tem sido cada vez mais freqüente no ambiente escolar, não somente para motivar os alunos, como também para atualizar a concepção de fonte de aprendizado que valoriza as imagens sejam elas paradas ou em movimento produzidas no seio da sociedade e veiculadas a interesse de determinados grupos sociais. O problema é que, em muitos casos, essas imagens são introduzidas nas aulas descontextualizadas e com uma abordagem que não favorece o processo ensino aprendizagem, ou seja, o que era pra ser uma aula dinâmica e produtiva passa a ser uma aula chata e enfadonha.

Sendo assim, o contato direto dos indivíduos com a televisão nem sempre garante um total entendimento do que está sendo veiculado, então surgi o papel 
da escola como espaço de criticidade para que essa recepção midiática atue na formação e na construção de novos saberes que estejam atrelados ao seu contexto e as mudanças que venham a ocorrer no interior da sociedade. É Preciso pensar o grau de influencia da mídia em nossas vidas, reconhecendo não só suas características alienantes, como também a sua possibilidade de fonte de aprendizado. É preciso explorar as ambigüidades. “Assistir televisão - como destaca Orozco (1997) - é um processo que se para além do ponto de contato entre os indivíduos e a tela". Não se trata de um processo linear do tipo estímuloresposta ou causa-efeito, mas sim de uma conjugação de fatores subjetivos, sociais e culturais e históricos que os levam a confiar nessa mídia, ou seja, existe mesmo que inconscientemente um processo de negociação entre o que a TV me informa e o que eu desejo ter como informação.

A televisão introduz em nossas casas o mundo e nos liga
instantaneamente a ele. Nossas crianças, diante de um aparelho de
televisão, sentem-se como se estivessem conectados com o planeta;
sentem-se como cidadãs do mundo, habitando uma aldeia global
(GADOTTI, 2005, p.24)

Neste sentido, torna-se indispensável à importância da televisão na comunicação contemporânea e inevitável o contato com o que ela veicula devido a sua forte característica de hibridação de mensagens. Orofino (2005) destaca que A TV e o rádio cobrem $98 \%$ do território brasileiro, levando informações, entretenimento, valores éticos políticos aos mais distantes recantos do país. Portanto, não há escola, por mais distante e diversa que seja que conviva sem a presença de alguma influência da cultura das mídias. Em outras palavras, não se trata de propor a substituição da palavra escrita por imagens, nem tampouco de utilizar a TV como reforço didático para as atividades de sala de aula, o que pretendemos é estimular uma reflexão crítica acerca dos conteúdos transmitidos pela TV. 


\subsection{Mídia e Educação Física}

Neste capítulo iremos buscar a aproximação da mídia (TV) com a Educação Física e seus desdobramentos. Também abordaremos trabalhos que contribuíram significativamente para o avanço desse campo de intervenção e que servirão de alicerce para o aprofundamento da temática em questão. Pois, acreditamos que a Educação Física tem como objeto a cultura corporal de movimento que trata das ações humanas: o jogo, o esporte, a dança, a ginástica e as lutas, orientadas para a realidade concreta às necessidades e motivações humanas. Por isso, entendemos que Educação Física está fundamentada num projeto pedagógico, nas teorias educacionais que direcionam a prática pedagógica rumo a transformação social. Sendo assim, teremos como objetivo desse capítulo elevar o pensamento teórico, a partir do trato com o conhecimento das pesquisas no campo da Educação Física, materializando as questões midiáticas dentro do currículo escolar.

Muitas disciplinas escolares se aproximam da TV com mais facilidade. Matérias como português, história e geografia encontram na programação da TV um material que vai de encontro aos seus conteúdos tradicionais. Partindo desse pressuposto, faremos a seguinte indagação: Como os discursos e as imagens veiculados pela TV acerca da cultura corporal de movimento estão presentes na prática pedagógica do professor de Educação Física?

Frequentemente, comentários e dúvidas sobre novas práticas esportivas e corporais, surgem nas aulas de Educação Física. Tais dúvidas se dão, ao grande espaço ocupado pela mídia no cotidiano de jovens, adultos e crianças. A mídia, como fenômeno importante na sociedade chega à escola ganhando uma forte 
influência no campo pedagógico, tornando-se uma grande problemática para Educação, em especial para a Educação Física. Sendo de grande importância a mídia no mundo atual, torna-se evidente sua influência no âmbito da cultura corporal de movimento, sugerindo diversas práticas corporais, reproduzindo-as, mas também as transformando e constituindo novos modelos de consumo (BETTI, 2001).

Neste sentido, a mídia passa a exercer uma forte influência sobre os elementos da cultura corporal de movimento em que ela veicula, tendo a TV como principal aliada no processo de transmissão de inúmeras informações referentes à Educação Física como: programas esportivos, transmissões constantes de jogos, debates sobre regras, valores, táticas, técnicas, aptidão física, modelos e padrões corporais, aspectos históricos, entre outros assuntos.

\begin{abstract}
Se cabe à Educação Física introduzir e integrar o aluno na cultura corporal de movimento, há que se considerar que: i) a integração há de ser do aluno concebido como uma totalidade humana, com suas dimensões físico-motora, afetiva, social e cognitiva, e ii) o consumo de informações e imagens proveniente das mídias faz parte da cultura corporal contemporânea, e portanto, não pode ser ignorada; pelo contrário, deve ser objeto e meio de educação, visando instrumentalizar o aluno para manter uma relação crítica e criativa com as mídias (BETTI, 2001, p. 97-98).
\end{abstract}

Assim, a mídia esportiva torna-se conteúdo da Educação Física escolar, cabendo a disciplina promover a retomada de uma formação cultural autônoma em relação à indústria midiática, tematizando o conteúdo, contextualizando, criticando e avaliando os meios e instrumentos da mídia esportiva e seu impacto no ser humano, a fim de formar o receptor-sujeito e, conseqüentemente, o cidadão crítico.

Sendo assim, o tema ganha relevância tendo em vista o caráter de centralidade do esporte na sociedade midiatizada, principalmente pela sua 
veiculação como mercadoria cultural e espetacularizada, bem como por sua representação na sociedade capitalista o que o leva ser um dos principais conteúdos da Educação Física. Mais do que isso, a lógica que pauta essa sociedade tenta transformar outras práticas corporais em mercadoria e para tanto as esportivizam, ou seja, fazem com que essas práticas adquiram regras universais para poderem ser consumidas independentes da localização no globo. (BETTI, 1998).

Porém, uma vez esportivizadas, tais práticas corporais se tornam espetáculo orientado ao alto rendimento, ou seja, acabam afastando os cidadãos comuns da prática cotidiana de uma atividade física, que passa a ser teleespetáculo. Assim o sujeito ou, porque não, assujeitado "passa sucessivamente de praticante a espectador, deste a telespectador, e agora, a teleconsumidor" (PIRES, 2006, p. 22).

Desta forma, o professor deve levar o aluno a compreender o sentido implícito e explícito das informações oferecidas pela mídia, contribuindo para formação de um receptor ativo, seletivo e em relação aos sentidos originais das mensagens midiáticas, reconstruindo seu próprio significado. Para Pires (2006, p.19), cada vez mais a mídia ganha importante espaço na "construção dos saberes/fazeres da cultura de movimento e esportiva", intervindo no campo da Educação Física escolar, tendo o esporte como forte aliado.

Segundo Pires (2006) é assim que a mídia se insere contexto escolar passando a influenciar conceitos, concepções e práticas, que chegam até a Educação Física transformando as práticas corporais em bens de consumo. Então, cabe a esta disciplina, área de conhecimento humano que tem como campo de atuação tratar científica e pedagogicamente da cultura corporal de movimento. 
Discutir o que é movimento, corpo e esporte para a mídia, como ela os tem concebido e as representações sociais que as pessoas fazem a partir de tais informações, parece se constituir em questões fundamentais à Educação Física, nas suas inter-relações e interfaces com o campo da Comunicação Social (PIRES, 2006, p.2)

Desse modo, pode-se inferir que a mídia televisiva coloca questões de ordem pedagógicas para ser refletida pela Educação Física escolar, pois se as informações e imagens provenientes da televisão veiculam elementos da cultura corporal de movimento, devem também ser objeto e meio de educação, objetivando preparar os indivíduos para estabelecerem uma relação crítica e criativa com os discursos difundidos por essa mídia. Sendo assim, o discurso televisivo sobre a cultura corporal de movimento deve ser interpretado buscando decifrar sentidos nele presentes, e refletir criticamente sobre suas repercussões na Educação Física Escolar. (PIRES, 2006)

Dessa forma, o professor deve discutir com os alunos/cidadãos possibilidades de utilização de vídeos, documentários, revistas, jornais e entre outras mídias a partir de um olhar epistemológico de uma Educação Física concebida como apropriação e transformação da cultura corporal de movimento, tratando de assuntos polêmicos e atuais que facilitem o desenvolvimento do conteúdo e consequentemente do educando. "Em síntese, a tarefa teórica e prática da Educação Física deve ser a do esclarecimento, visando desvelar pela crítica e pela razão o conjunto de objetivos e interesses que configuram a mensagem midiática sobre o esporte" (PIRES, 2006, p. 32).

Dessa maneira, ainda de acordo com Pires (2006), tornam-se indispensáveis novos olhares epistemológicos para compreensão da recepção midiática, tendo como base, pesquisas que se afinam com o campo dos estudos culturais latino-americanos, que retomam o debate acerca dos estudos sobre a recepção midiática, numa perspectiva da formação do "receptor-sujeito". Ou 
seja, um sujeito antes visto como consumidor meramente passivo, agora assumindo status de também produtor, capaz de desenvolver uma reflexão seguramente crítica em relação aos sentidos originais dos conteúdos midiáticos, reconstruindo seu próprio significado, conforme suas próprias estruturas de recepção.

Neste sentido, volta-se a responsabilidade pedagógica ao professor de Educação Física pela formação do receptor-sujeito, sendo de fato agentes de esclarecimento, contribuindo para reflexão crítica, ativa, seletiva e autônoma durante o processo de ensino aprendizagem para que o aluno/cidadão possa atribuir controle democrático dos meios de comunicação e da qualidade das suas programações, levando em consideração seu cotidiano, heterogeneidade das temporalidades culturais e as práticas de consumo simbólico, perspectivas já apontadas pelos estudos culturais latino-americanos.

Sobre os estudos midiáticos que tem como foco o discurso televisivo no campo de Educação Física chamamos atenção ao trabalho de Betti (1998) intitulado "Janela de vidro: esporte, televisão e educação fisica" que problematiza o discurso da televisão sobre o esporte e suas estratégias de espetacularização desse fenômeno e seus impactos na escola. Por fim, realiza-se a apropriação crítica, concebida como a direção de pensamento aberta pelo discurso, que alicerça a busca de novos sentidos para as tarefas educacionais da Educação Física, concluindo que a formação de um espectador crítico e sensível é uma nova tarefa que a ela se impõe.

Pires (2000) em seu trabalho intitulado "A Educação Física e o Discurso Midiático:abordagem crítico-emancipatória em pesquisa-ação no ensino de graduação. Subsidios para a Saúde?" Teve como objetivo compreender criticamente o cenário produzido nas relações entre Educação Física e mídia 
esportiva na cultura contemporânea. Tendo como resultado buscar intervenções no campo da Educação Física sobre a temática da recepção, tendo possibilidades de aplicação da proposta para abordagem de outros temas da Educação Física, igualmente influenciados pela mídia, como sua relação com o campo da saúde.

Antunes (2007) construiu um estudo sobre intitulado “Análise da recepção midítica em jovens escolares ao discurso midiático-esportivo construído e veiculado durante a Copa do Mundo de 2006". Também constatamos que tanto a escola, como a educação física, necessitam repensar suas ações pedagógicas, no sentido de investir, cada vez mais, numa formação que não esteja isolada do mundo vivido pelos sujeitos. Por isso, propõe-se pensar numa perspectiva de ensino mais crítica, que atenda as necessidades de uma educação para a mídia.

Outro estudo utilizando como objeto a Copa do Mundo de 2006 foi o de Freitas (2008) onde foi feito análise da produção discursiva referente à desclassificação da seleção brasileira, mais especificamente da derrota no jogo contra a seleção francesa. Tendo como conclusão que os discursos midiáticos produzem efeitos de verdades a partir de uma multiplicidade discursiva, e não de um metadiscurso.

Outro trabalho que nos dá elementos do discurso televisivo é estudo de Lisboa (2008) ao descrever e analisar a cobertura esportiva realizada pelo programa Jornal Nacional (Rede Globo) em relação aos Jogos Pan-americanos Rio/2007, tendo como objetivo constatar, além dos aspectos quantitativos ligados ao tempo de transmissão, as questões relacionadas às tendências, ênfases e representações veiculadas por tal programa no que se refere ao Esporte/Educação Física. Tendo como resultados que a grande presença dos Jogos Pan-americanos na pauta de notícias veiculadas pelo Jornal Nacional no período analisado, sendo que sua grande visibilidade encontra respaldo nos processos de apropriação do 
fenômeno esportivo pela instância midiática que, além de veicular valores e representações, também age sobre critérios comerciais e mercadológicos, sendo assim também "promotora de notícias”, uma vez que, neste caso, a própria empresa "Rede Globo" promoveu os Jogos.

Sobre as tendências observadas na cobertura tele-jornalística do Panamericano pelo noticiário, verificaram que além da incorporação de inúmeros recursos tecnológicos nas transmissões, a ênfase em modalidades que geram expectativas e resultados positivos, necessários para a congregação do exercício da nacionalidade brasileira, que se desejava vitoriosa e integrada aos meios. Para tanto, uma das estratégias utilizadas continua sendo a personificação das vitórias e desempenhos em ídolos/atletas que tão bem interessam aos objetivos comerciais e simbólicos da televisão/mídia.

Na mesma linha de investigação se faz presente o trabalho de Rigo (2009) intitulado "A seleção brasileira de futebol na copa América de 2007: uma demanda discursiva inacabada" que traz um olhar a respeito do discurso do futebol e suas relações com a cultura contemporânea, abordando as produções discursivas durante a Copa América de 2007 que tratam da seleção brasileira sob o comando de Dunga. Teve como resultado Como conclusão do estudo, apontamos para o campo midiático como um espaço onde circulou e foi produzida uma pluralidade discursiva que colocou em disputa diferentes possibilidades de identidades para a Seleção Brasileira.

Santos (2009) elaborou um estudo intitulado " $O$ discurso midiático dos jogos pan-americanos rio/2007 e a candidatura aos jogos olímpicos de 2016: o "trampolim" do Brasil. Teve como objetivo central analisar e compreender a configuração do discurso televisivo da Rede Globo de Televisão na cerimônia de abertura dos Jogos Pan-americanos do Rio - 2007 no que se refere à ideia de 
"nível olímpico de organização". Teve como resultado concluímos que a citada emissora de TV lança discursos que foram a favor ou que agiram em prol de uma especificidade: o desejo de uma possível realização de uma edição dos Jogos Olímpicos no Rio de Janeiro em 2016. Porém, para que a concretização desse "sonho", é essencial um " trampolim" que impulsione algo, que leve algo, como num passe de mágica, de um lugar a outro, de uma condição à outra: esse trampolim representa a realização (com sucesso) dos Jogos Pan-americanos no Rio.

Medeiros (2012) traz um trabalho intitulado "O futebol feminino no discurso televisivo" que teve como objetivo analisar as características discursivas da narração de partidas disputadas pela equipe do Santos Futebol Clube na Copa Libertadores de Futebol Feminino. Teve como resultado que nas narrativas investigadas, sobressai o apelo estético em torno das mulheres, em detrimento aos aspectos técnicos e táticos da prática esportivo-competitiva em si. Por essa razão, os sentidos incorporados à prática profissional do futebol feminino continuam carecendo de uma ressignificação, como apontado por Goellner (2010). Entendemos que tal ressignificação perpassa todo o processo comunicativo.

Mezzaroba (2011) intitulado "A copa do mundo de futebol da/na globo: um estudo sobre o agendamento de 2014 no jornal nacional" nos apresenta um estudo cujo objetivo é o de investigar o agendamento midiático-esportivo realizado na Copa do Mundo de Futebol/2010 projetando a Copa de 2014 que será realizada no Brasil. Teve como resultado o utiliza este fenômeno esportivo particular como "espelho da imagem do próprio país", lançando, para isso, valores estéticos, apelos emocionais e táticas sensacionalistas, auxiliando empresas divulgadoras de produtos a fortalecer ou posicionar suas marcas ao 
valor que o esporte, e sobretudo o futebol se prestam.

Sendo assim, partindo desse breve panorama podemos perceber que os discursos televisivos nos possibilita reflexões que permitem afirmar que a língua se insere na história para produzir sentidos, pois a partir da materialidade dos discursos passamos a verificar que as informações não estão desinteressadas do ponto de vista ideológico.

Dessa maneira, entendemos que as informações veiculadas são carregadas de mecanismos que merecem um estudo que vai muito além do que se vê, do que se ouve é necessário que se rompa com a visão de recepção midiática para que se possa entender o que hoje se denomina discurso.

\subsection{Recepção midiática}

Neste capítulo iremos refletir sobre os estudos que abordam a temática da recepção midiática a partir de sua estrutura teórico-metodológica para nos orientar no debate acerca da problemática das mediações, discutindo as perspectivas que pautaram as pesquisas na área tendo como ponto de partida as categorias, proposições e apropriações dos seus principais autores.

É oportuno destacar que mesmo enfatizando "o estudo de recepção midiática" sabemos que no processo de comunicação o receptor não fica unicamente nessa posição, ele também se torna emissor e é nessa lógica que vamos discutir essa interação desse processo. Antunes (2007) salienta que sob essa perspectiva os estudos de recepção ganham forças e denunciam a necessidade de serem alvo de pesquisas, investigações, análises, reflexões; enfim 
elemento orientador de uma busca mais qualificada pelo conhecimento e entendimento de quem são como funcionam as mediações e a importância delas na recepção dos sujeitos, uma vez que os meios entenderam que a audiência ou os públicos não são entes indiferenciados ou passivos, contudo têm uma forte diversidade de gostos e modos de consumir. Neste sentido, não podemos cair no equívoco de tratar o receptor como ponto de chegada, e sim de partida, sem desconsiderar a influência do processo de produção de informação.

A partir dos anos 1970 ocorreram os primeiros estudos sobre os efeitos produzidos pelas mensagens midiáticas (BENJAMIN, 1983; MORIN, 1984). No entanto, em meados dos anos de 1980, um outro tipo de preocupação parece despertar interesse nos pesquisadores da área. Os estudos no campo da comunicação passaram a tentar compreender os diferentes significados que as audiências construíam a partir das mensagens dos meios de comunicação. Antes deste período, os acadêmicos que adotavam teorias críticas ou marxistas costumavam tomar como um dado da realidade o poder da mídia, ignorando assim os processos de recepção das suas mensagens (FERRÉS, 1994).

O novo paradigma, a pesquisa de recepção, passou a enfatizar disputas ideológicas no processo de comunicação, utilizando métodos qualitativos (etnografia, entrevistas abertas, grupos focais, etc.) e tratando os membros da audiência como agentes que interpretam ativamente o conteúdo da mídia. A seguir discutirei os principais enfoques desta tradição.

Essa mudança de perspectiva no processo comunicativo chama atenção para uma transformação no eixo de análise. Muitos pesquisadores começaram a compreender o fenômeno da cultura das mídias segundo a perspectiva de uma audiência ativa. Essas investigações passaram a ser chamadas de Teorias da recepção. Neste caso, precisamos então, fundamentalmente, levar em conta o 
espaço central que a mídia ocupa na constituição das relações sociais que tecem no mundo contemporâneo (MARTÍN-BARBERO, 1997; THOMPSON, 1998; SILVERSTONE, 2002; LOPES, 2002, entre outros).

Conforme Setton (2011) é possível apontar quatro abordagens dos estudos de recepção com origem em diversas tradições disciplinares. A primeira delas proveniente da tradição dos Estudos Culturais críticos anglo-americanos, tinha como base as teorias neomarxistas e se submetia a uma considerável influencia da análise estrutural, um dos seus representantes seria Louis Althusser; a segunda com origem na tradição do interacionismo simbólico, seria próxima das abordagens funcionalistas; a terceira, seguidora da tradição dos Estudos de Consenso Cultural,teria raízes na antropologia cognitiva cultural de teóricos como Clifford Geertz, Claude Lévi- Strauss e Victor Turner; e, por último, a abordagem resultante dos interesses na cultura popular. Essa última tradição entende a mídia como um texto e enfatiza a construção do significado das comunidades interpretativas (jovens, mulheres, trabalhadores sindicalizados, etc.).

Para estudar a teoria da recepção midiática é oportuno então observar que as práticas de recepção mediática na verdade podem ter se dedicado muito mais ao estudo das relações das mídias com as pessoas, e do lugar destas com aqueles, em função de um fim que se oculta no social e que na verdade se define como sujeito da própria comunicação. Esse viés a um só tempo do objeto e da metodologia de seu estudo confere a possibilidade de dizer que ao invés de se estudar a relação das pessoas com a sociedade através das mídias, em sua função de mediação, os estudos sobre recepção midiática têm buscado o social e o cultural numa perspectiva que se concentra muito mais no estudo da relação entre as mídias e as pessoas. Assim, salienta-se a pertinência da afirmação que 
sugere esse deslocamento do objeto de estudo da comunicação "dos meios às mediações" (MARTIN-BARBERO, 1997).

Nessa lógica, surge a problemática da recepção sob o viés das mediações, que inaugura uma reformulação teórica e metodológica no campo das pesquisas em comunicação na América Latina, obtendo crescente reconhecimento na comunidade acadêmica; pela ruptura epistemológica ocorrida, pois segundo Jacks (1999) o lugar estratégico da comunicação na configuração de novos modelos de sociedade é uma maneira de ultrapassar a noção hegemônica de que ela é regida apenas pelo mercado. De acordo com Antunes (2007) o receptor passa a não compartilhar a concepção dos produtos da indústria cultural, todavia se torna um agente capaz de produzir em meio a sua heterogeneidade diversos sentidos que são relacionados ao seu contexto social.

Mediação pode ser entendida, portanto, como um conjunto de
elementos que intervêm na estruturação, organização e reorganização
da percepção da realidade em que está inserido o receptor, tendo poder
também para valorizar implícita ou explicitamente esta realidade. As
mediações produzem e reproduzem os significados sociais, sendo o
'espaço' que possibilita compreender as interações entre a produção e
a recepção (JACKS, 1999, p.4)

Jacks (1999), aponta que os estudos relacionados a essa temática integraram-se tardiamente nessa perspectiva e, por isso, apresentam uma grande lacuna entre os pressupostos teóricos e metodologias empregadas. O que se verificou, muito na década de 1990. Segundo Antunes (2007) provavelmente, em função da falta de uma estratégia de multimétodos que conseguisse observar e analisar a riqueza e diversidade das mediações. Pois, essas, não conseguem ser analisadas se engessadas por métodos científicos que não apresentem possibilidades mais flexivas no tratamento a ser dado pelo pesquisador. Antunes (2007), aponta Nilda Jacks como a pioneira nos estudos brasileiros de recepção sob uma perspectiva multimetodológica junto ao paradigma das mediações. 
Estes estudos permitem analisar o cenário em que os receptores constroem e reconstroem suas práticas, subjetividades e identidades com o objetivo de compreender suas relações com o mundo social. Jacks (1995) entende que não basta somente o conhecimento do contexto do cotidiano, mas todas as instâncias e lógicas da produção, assim como as mais amplas características da cultura em questão.

Deslocar o eixo das pesquisas para as mediações não significa desconsiderar a importância dos meios, mas evidenciar que o que se passa na recepção é algo que diz respeito ao seu modo de vida, cuja lógica deriva de um universo cultural próprio, incrustado em uma memória e em um imaginário que são decorrentes de suas condições de existência. (JACKS, 1995, p.153)

Setton (2011) traz em seu livro - Mídia e educação - um olhar para a análise midiática, já nessa perspectiva, pois aponta para um receptor ativo e participativo no processo de construção de sentidos nas sociedades modernas, ou seja, chama a atenção para o fato de que a recepção é um lugar de criação, é um espaço e possibilidade de ressignificação e transformação de significados oferecidos pelas mídias.

Zanchetta Júnior (2006), em seu trabalho - Estudos sobre recepção midiática e educação no Brasil -traça um panorama sobre a evolução dos estudos relacionados à recepção midiática e sobre como a escola brasileira se apropriou dessas idéias. Problematizando, as características das propostas da área de Comunicação para a formação midiática, sugerindo-se uma perspectiva 'escolar' para essa formação centrada na formação histórica-política do professor e na delimitação de um território específico para a discussão sobre cidadania dentro da escola.

Outro trabalho que segue essa abordagem é de Salgado (2006), intitulado Da recepção à produção de mídia: as crianças, a cultura midiática e a educação - 
onde procura dar visibilidade as teorias de recepção e teve como objetivo compreender os modos como as crianças interagem com os desenhos animados contemporâneos, construindo valores e conhecimentos nas interfaces com esses textos midiáticos.

Sousa Junior (1999) traz em seu trabalho- A recepção midiática e a perspectiva da "dupla mediação"- onde ensaia reflexões a respeito e em especial quanto às possibilidades de compreensão da recepção mediática desde a perspectiva do que vem sendo denominado de "dupla mediação".

Santos e Mezzaroba (2015), no seu trabalho - ESPORTE E MÍDIA: um estudo de recepção ao discurso midiático esportivo e algumas implicações na escola - esta pesquisa se caracteriza como um estudo de recepção dos conteúdos midiáticos com intuito de entender essas relações entre o emissor e o receptor, com mais ênfase ao que pode ser interpretado e compreendido pelos sujeitos receptores dos conteúdos midiáticos.

Com a autoridade de ser um dos pioneiros e ainda dos mais ativos entre os pesquisadores da área na América Latina, Martin-Barbero (1997) considera que a recepção é um lugar novo, de onde deve ser repensada toda a pesquisa em comunicação. O modelo que denomina mecânico - aquele em que informação e comunicação são tomadas como sinônimos, assim como necessariamente coincidentes seriam os significados pretendidos pelo produtor e os sentidos atribuídos à mensagem por cada receptor - não permite que as diferenças culturais que constituem estruturas mediadoras do processo de recepção midiática sejam consideradas nas investigações, porque nele inexistem modelagens metodológicas que dêem conta da interpretação desta infinidade de variáveis da cultura que interferem na produção de sentidos. 
Para Martin- Barbero (1997), a etapa da recepção das mensagens não deve ser observada como uma simples parte do processo de comunicação. Ao contrário, a recepção é um lugar novo, de onde devemos repensar os estudos e a pesquisa em comunicação. Para o autor, devemos compreender a construção do significado pela audiência como resultado de uma confrontação e uma negociação de muitos atores produtores de cultura. Segundo ele, os estudos de recepção devem enfocar os locais dos quais se podem observar e compreender a interação entre lógicas de produção e a da recepção das mensagens da cultura das mídias. Ele denomina esses processos de mediações, ou seja, interações de sentidos, a partir de lutas e ou aceitação, resistências e ou transformação dos significados das mensagens porque são esses procedimentos que reúnem e dinamizam as negociações entre diferentes lógicas culturais.

Ao apresentar esse novo enfoque, Martín-Barbero (1997) rompe com uma leitura mecânica do processo em que não se encontram sujeitos nem intercâmbios culturais. Rompe com um modelo em que comunicar "[...] é fazer chegar uma informação, um significado já pronto, já construído, de um plano a outro. Tendo a recepção como um ponto de chegada daquilo que já está concluído”. (MARTÍN-BARBERO, 1997, p.39).

Este autor considera que a leitura feita cria uma notável confusão na construção do entendimento do fenômeno da comunicação de massa. Ou seja, essa perspectiva mecânica e linear do processo comunicativo reforçaria um entendimento de que tudo aquilo que fosse divulgado pelas mídias seria aceito sem nenhum tipo de mediação cultural; em outras palavras, é como se os receptores fossem "esponjas" que tudo sugariam.

Dessa forma, essa perspectiva linear estaria confundindo a significação da mensagem com sentido dado pelos usuários a esse processo; estaria reduzindo o 
sentido e a moralidade dessas práticas na vida das pessoas ao significado que veicula a mensagem. Em síntese, essa concepção estaria confundindo o sentido dos processos de comunicação na vida das pessoas com o significado dos textos, das mensagens, ou mesmo das linguagens dos meios.

Portanto, a verdadeira proposta do processo de comunicação e dos
meios não está nas mensagens, mas nos modos de interação que o
próprio meio - transmite ao receptor. A Recepção é um espaço de
interação, é um processo de interação de sentido. Não é uma somatória
de mensagens. É uma circulação dos discursos, é no comentário sobre
as mensagens que o público consumidor negocia sentidos (MARTíN-
BARBERO, 1997, p.56)

O receptor efetuaria permanentemente uma "negociação de sentidos", a ponto de rever sua própria história a partir da interação com os meios, e também de nortear, como sujeito, o papel da mídia. Um de seus objetos de estudo para explicar como se dá o relacionamento entre os meios e a cultura popular é a televisão. Para ele, o modelo de televisão da América Latina é hegemônico e resiste a diferenças, algo que as teorias pessimistas atestaram fartamente, mas a televisão permite brechas e expressa contradições que tornam visíveis a "não unificação do campo e do mercado simbólico". Daí a sobrevivência de um padrão melodramático nas novelas brasileiras ou mexicanas, ou ainda nos programas de variedades e mesmo nos telejornais. (SETTON, 2011)

Martín-Barbero (1997) analisa a televisão a partir de pontos nucleares de recepção, como a família, a escola, o trabalho. A insistência da tevê em retomar permanentemente o que ela disse antes é vista menos como estratégia "alienante" e mais como deliberada resistência popular aos padrões hegemônicos. A televisão deve ser lida a partir da dinâmica de seus gêneros e não com instrumental da cultura culta. 
Para Guillermo Orozco (1997), por mediação pode-se entender um processo estruturante que configura tanto a interação dos telespectadores com os meios de comunicação quanto a criação, por parte dos receptores, dos sentidos dessa interação. Ele retomar o conceito de mediação para demonstrar a necessidade de elaborá-lo em termos mais sistemáticos, na direção de inseri-lo como elemento teórico-metodológico fundante desta nova perspectiva da pesquisa sobre recepção. Segundo ele, mediação deve ser entendido como um processo estruturante que configura e reconfigura, tanto a interação dos telespectadores com os meios de comunicação quanto a criação, por esta mesma teleaudiência, dos sentidos dessa interação.

A múltipla interação dos sujeitos sociais com os meios de
comunicação e tecnologias de informação, converteu-se em um dos
acontecimentos mais distintos e relevantes da vida cotidiana das
sociedades e culturas contemporâneas. Sem ser totalizante, essa
interação comunicativa constitui atualmente um dos eixos principais
para entender-se a ação social em seu conjunto. Tanto que já não é
mais possível referir-se à educação, à política, à economia e à cultura
sem incorporar a elas os meios e suas mediações (OROZCO, 1997,
p.13)

Assim, conforme o autor, atribuindo-se um enfoque integral para a audiência torna-se possível pensar numa educação crítica para a recepção, com vistas à emancipação do telespectador, através dos esforços de tornar transparentes e menos assimétricos os processos de interação entre emissores e receptores. Entendendo, porém, a mediação como um processo complexo e difuso, Orozco (1997, p.58) desenvolve as bases do que denominou "dialética da recepção", esquematizando um modelo analítico das múltiplas mediações que interagem na produção de sentidos, composto por categorias que têm a comunicação e a cultura como principais eixos articuladores: mediações individual, situacional, institucional e tecnológica, a saber: 
a) mediação individual, dividida em estrutural, cognoscitiva, estética e moral: refere-se às condições próprias do sujeito da recepção, estando a primeira ligada a fatores como idade, sexo, etnicidade, etc.

b) mediação situacional: reflete sobre os cenários e as condições espaciais através das quais o telespectador assiste à TV, podendo ser compreendida a partir de respostas a questões do tipo: assiste-se só ou em companhia de outros?

c) mediação institucional: destaca as diversas instituições sociais de que faz parte o sujeito receptor e que exercem importante papel na significação dada à comunicação. Doutrinas religiosas ou ideológicas, posições políticas, saberes práticos e conhecimentos profissionais específicos, entre outros, constituem-se em diferenciais para a configuração da recepção midiática.

d) mediação tecnológica: refere-se a formas particulares do meio de reproduzir e recriar eletronicamente as características sociais recolhidas da realidade.

Apesar da aparente organização sistemática deste conjunto de estruturas de intermediação da recepção, Orozco (1997) alerta para a complexidade do sistema de mediações múltiplas, que não devem ser entendidas como instâncias estanques, lineares e estáveis. Pelo contrário, a interação TV-receptor compreende combinações entre as mediações que podem variar ao longo do tempo, pela ocorrência de fatos que alterem o cotidiano do receptor ou ainda pela inclusão de novos elementos culturais no processo comunicacional.

Autores como Martín-Barbero (1997) e Orozco (1997) subsidiam proposta mais recente, marcada pela observação de como se configuram identidades 
culturais a partir da negociação de sentidos entre quem produz e quem recebe as mensagens midiáticas. Não haveria recepção passiva, mas uma permanente busca de ressignificação, por parte do leitor, em relação às mensagens e suportes midiáticos. As pessoas selecionam, subvertem, descartam, rearranjam e mesmo produzem as informações de seu interesse, a partir de critérios provenientes de seu horizonte cultural e não por critérios ditados pelos meios midiáticos. Esta proposta ganha prestígio na América Latina e em vários países europeus. Mesmo ainda iniciante na Educação, tal pensamento ampara boa parte do ideário da área de Comunicação no Brasil.

\subsection{Discurso e mídia}

As pesquisas e intervenções pedagógicas em Educação Física constituemse a partir do corpo e do movimento, problematizando as práticas corporais. $\mathrm{Ou}$ seja, os movimentos são negociados dentro de um espaço/campo que passam a ser interpretados produzindo significados. E esses movimentos são explorados pela indústria midiática e muitas vezes a própria indústria os interpretam e divulgam como única e fiel realidade, sem valorizar a possibilidade de interpretação do seu receptor. E como ficam os discursos dos receptores à luz da cultura corporal de movimento veiculada pela mídia?

Dessa forma, entendemos que o discurso do receptor deve ser analisado de forma mais acurada sempre articulada com o seu mundo simbólico e social. Segundo Pêcheux (1996), o discurso constitui-se como o espaço de confluência entre a língua e a história e, por consequência, as ideologias e as relações sociais coexistem nela. Neste sentido, não podemos analisar e por seguinte entender a 
Educação Física como uma espécie de meta - educação física. É preciso ter uma noção de totalidade e relacioná-la com outras áreas. Sendo assim, se nos propomos analisar a recepção do discurso midiático, se torna necessário que busquemos alicerce na teoria da Análise do Discurso.

A Análise do Discurso (AD) surge, assim, com o intuito de uma intervenção transformadora, que visa combater a análise do texto estritamente linguístico, passando a levar em consideração os embates sócio ideológicos nos seio da sociedade, estabelecendo assim, novos conceitos de língua, historicidade, sujeito e etc. Guerra (2009) entende que essa nova orientação parte da relação da linguagem com a exterioridade do discurso, ou seja, aquilo que estava fora do campo lingüístico passa a ter uma importância significativa como: as condições de produção do discurso; o interdiscurso; memória discursiva.

Com base nessa relação da linguagem com a exterioridade, a AD recusa as concepções de linguagem que a reduzem ora como expressão do pensamento, ora como instrumento de comunicação. A linguagem é entendida como ação, transformação, como um trabalho simbólico em "que tomar a palavra é um ato social com todas as suas implicações, conflitos, reconhecimentos, relações de poder, constituição de identidade etc." (ORLANDI, 2001, p.17).

Guerra (2009) salienta que no campo da AD, o discurso se constitui a partir do interdiscurso: todo discurso produz sentidos a partir de outros sentidos já cristalizados na sociedade. Courtine (1999) define interdiscurso como séries de formulações discursivas marcando, cada uma, uma enunciação distinta e dispersa, articulando-se entre elas em formas lingüísticas determinadas: citandose, repetindo-se, parafraseando-se, opondo-se, transformando-se. Então, podemos conceber a memória discursiva como sendo esses sentidos já cristalizados, legitimados na sociedade e que são reavivados no intradiscurso. Para Pêcheux (1996), a memória discursiva não se trata de uma lembrança, mas de um espaço onde se inscrevem ideologias, e crenças, que são a condição 
essencial de produção e da interpretação de seqüências discursivas, de sentidos. Este é, muitas vezes, apagado pela ideologia, para produzir o efeito de homogeneidade discursiva, espaço de deslocamentos, de retomadas, de conflitos.

Gregolin (2001, p.13) considera que

[...] empreender a análise do discurso significa tentar entender e explicar como se constrói o sentido de um texto e como esse texto se articula com a história e a sociedade que o produziu. O discurso é um objeto, ao mesmo tempo, lingüístico e histórico; entendê-lo requer a análise desses dois elementos simultaneamente.

$\mathrm{O}$ discurso midiático tem sua coerência à medida que resgata a memória do leitor, numa reconfiguração do passado. Isso explica uma das características fundamentais da Análise do Discurso que é seu caráter transdisciplinar, pois ela se apoia em disciplinas do campo das ciências humanas (filosofia, história, psicanálise, sociologia, literatura, etc.).

Sendo assim, a todo o momento somos obrigados a fazer uso de nossa memória discursiva, trazendo à tona textos que já circularam na sociedade. Veja, por exemplo, a música que embalou o Brasil na Copa do Mundo de 1970 - "Pra frente Brasil, salve a seleção". Ao ouvir essa música, resgatamos muitos outros fatos que circularam nessa época, como aqueles relacionados à ditadura, à crise econômica, à censura, etc. É uma espécie de entrecruzamento de vozes, isso se torna interpretável através de criação de ilusão de sentido. "A ilusão é um recurso muito utilizado pela mídia como uma construção que permite ao ouvinte formas simbólicas de representação da realidade concreta" (GREGOLIN, 2001, p.25). Sendo assim, o sujeito não é a fonte absoluta do sentido e significado, está longe disso, pois ele se apropria de outros sujeitos e falas. É através da interação da verbal que ele molda o que dizer. 
Nos textos midiáticos, teia onde se cruzam textos e discursos, os sentidos só podem ser captados na heterogeneidade. A aparente instantaneidade da mídia interpela incessantemente o leitor através de textos/discursos, compondo o movimento da história presente por meio da (re) significações de mensagens e sinais enraizados no passado. Os gestos de interpretação fazem derivar do passado a interpretação contemporânea. "O leitor da mídia é interpelado a interpretar a história como se ela estivesse acontecendo diante do seu olhar" (GREGOLIN, 2001, p. 25). Cria-se, pelo instantâneo, a ilusão do fluir histórico e, consequentemente, a certeza ilusória de que se está acompanhando a Históriaem-curso.

O discurso midiático inscrito na relação da língua com a história é constitutivamente heterogêneo (COURTINE, 1981 apud GREGOLIN, 2001). Como discurso dialógico e polifônico, caracteriza-se pela presença de diferentes pontos de vista sobre um mesmo assunto, várias vozes que se entrecruzam, se multiplicam e se opõem em seus textos, e dessa forma que a mídia articula o sujeito à história e à prática social, inserindo a história no texto e o texto na história (KRISTEVA, 1969 apud GREGOLIN, 2001). Esse princípio da intertextualidade, que vem conferir ao caráter dialógico da mídia um sentido mais alargado, sublinha na escrita o seu caráter de teia, e permite olhá-la não na sua linearidade, mas na verticalidade, já que a informação é um mosaico de citações absorvidas e transformadas.

Devido a essa polifonia própria do discurso midiático, para ler os seus textos/discursos é preciso captar a relação que ele estabelece com os outros textos/discursos, que lhe são anteriores e exteriores, os quais repetem e transformam. No limite, a informação "[...] relaciona-se com o texto-História, que esquecido ou perdido, nele retorna; e sua escrita não é gravação no espaço 
virgem do seu suporte, mas leitura do texto apagado que a sustenta" (GREGOLIN, 2001, p.29). Dessa forma, o texto da mídia, que "[...] é produto de relações de contradição, de submissão ou usurpação de outros textos, só produz sentido ao ser percebido por um interlocutor-sujeito que reinterpreta o discurso do outro a partir do seu próprio discurso" (AUTHIER-REVUZ, 1990, p.22).

Como ressalta Caldas (2003, p. 1): “[...] o discurso não é neutro, a língua não é o espelho da realidade, mas do sujeito que, ao produzir um enunciado, está necessariamente interferindo, interpretando, reformulando, conferindo um novo sentido". Pêcheux $(1996$, p.) reforça a ideia, de que "[...] um discurso não pode ser analisado como um texto, pois ele não é unicamente uma letra morta, mas fruto de situações concretas, dentro de um período histórico, em um jogo de interesses que o fizeram aflorar".

Pêcheux (1996) considera que para a AD, o sujeito é essencialmente ideológico e histórico, pois está inserido num determinado lugar e tempo. Com isso, ele vai posicionar o seu discurso em relação aos discursos do outro, estando inserido num tempo e espaço socialmente situados. No imbricamento entre o lingüístico e o social, a enunciação passa a ser um fator relevante para a interpretação, para a constituição do significado. Aliado a esse fato, mobilizaremos a noção de Pêcheux (1996), que afirma que a interpretação é um "gesto", isto é, um ato no nível simbólico. É o lugar próprio da ideologia em que a interpretação é "materializada" pela história.

E como não existe discurso sem sujeito e nem sujeito sem ideologia, como abordam teóricos da Análise do Discurso (ORLANDI, 2001; BRANDÃO, 1998), o meio midiático caracteriza-se como um cenário para a produção de sentidos de sujeitos que se manifestam ideologicamente. Fairclough (2001) alerta que as conexões entre linguagem e exercício de poder não têm ficado clara entre 
as pessoas: "Pode-se considerar que a mídia efetiva o trabalho ideológico de transmitir as vozes do poder em uma forma disfarçada e oculta" (FAIRCLOUGH, 2001, p.144).

O que marca as diferentes posições do sujeito, dos grupos sociais que ocupam territórios antagônicos, caracterizando tais embates, é a ideologia, é a inscrição ideológica dos sujeitos em cena. Por tanto, ideologia é imprescindível, é inerente ao discurso (FERNANDES, 2007, p. 24).

Guerra (2009) destaca que a inserção dos aspectos ideológicos no bojo da discussão implica o apontamento de uma nova instância da linguagem: o discurso, que vai além de instrumento de comunicação ou suporte de pensamento, visto que representa a interação, um modo de produção social em que se manifesta a ideologia mediadora entre o homem e a sua realidade. Segundo a autora, a construção de um método de compreensão desse novo objeto de linguagem impulsiona a instituição de uma nova ciência que, ao circunscrever o aspecto discursivo, dá conta da complexidade da língua enquanto fato social e histórico.

Dessa maneira, a mídia representa uma poderosa arma para atores que pretendem se manter dominantes dentro da lógica social. Então, dessa forma, forças hegemônicas procuram controlar a constituição do discurso a partir da difusão, da manutenção e de tentativas de perpetuação de ideologias, tomados como instrumentos que viabilizam o poder, ou melhor, que sustentam as relações de poder através de determinadas produções discursivas, podendo criar verdades ideológicas pertinentes a determinados grupos, consoantes a seus interesses.

Nesse sentido, o discurso passa a ser a linguagem utilizada como a representação da prática social e traz pontos de vistas particulares, elaborados por intermédio de uma construção arquitetada pelo produtor do texto (FAIRCLOUGH, 2001). Sendo assim, a mídia é a responsável por trazer a tona 
fatos que se tornarão os referentes da realidade social para aqueles que participam dessa realidade e contribuirá para a construção das imagens que essa realidade terá para esse grupo.

O sentido de uma palavra, de uma expressão, de uma proposição, etc., não "existe em si mesmo" [...] mas, ao contrario, é determinado pelas posições ideológicas colocadas em jogo no processo sócio-histórico no qual as palavras, expressões e proposições são produzidas (PÊCHEUX, 1996, p. 190).

Dessa forma, a produção das informações não é neutra, nem desinteressada nela se encontram, entrecruzando-se, os interesses políticos e ideológicos daqueles que a produzem e a divulgam. A informação trazida pela mídia é criada a partir de determinados recursos e fundamentos préestabelecidos, o que remonta à subjetividade na prática midiática, pois o discurso propõe leituras e releituras do mundo a qual pertencemos.

\subsection{Discurso e ideologia}

Como vimos no capítulo anterior para falarmos em discurso, precisamos considerar os elementos que têm existência no social, nas ideologias e na História. Com isso, podemos afirmar que os discursos não são fixos, estão sempre se movendo e sofrem mutações, acompanham as transformações sociais e políticas de toda natureza que integra a vida humana.

A concepção francesa de Análise do Discurso afirma que o discurso é articulação do linguístico com o social, tendo como seu papel principal a materialização do processo enunciativo. Dessa forma, “[...] a linguagem passa a ser um fenômeno que deve ser estudado não só em relação ao seu sistema 
interno, enquanto formação linguística, mas também enquanto formação ideológica” (BRANDÃO, 1998, p.17).

Produzido pela prática do discurso, instância de materialidade ideológica, o trajeto de leitura do sentido é atravessado pela instituição sócio-histórica que "governa a atitude e a tomada de consciência concreta dos homens face a objetos reais de sua existência social e individual e de sua história" (ALTHUSSER, 2001, p. 93).Por isso, a dimensão discursiva é fundamental, sendo a ideologia essencialmente discurso, é a análise dos discursos que pode permitir a sua desconstrução racional. Segundo Pecenin (2008) formação discursiva diz respeito ao princípio geral de dispersão e regularidade (uma ordem, correlações, posições, funcionamento, transformações) entre os objetos, os tipos de enunciação, os conceitos e as escolhas temáticas sobre o qual se agrupa um certo número de enunciados, que manifestam uma incessante vontade de verdade.

A formação linguística, por sua vez "[...] é caracterizada pela presença do enunciado que não pode ser confundido de maneira alguma com um aglomerado de frases, mas sim um conjunto de ideias que dão sentido ao texto" (FIORIN, 1999, p.30). Dessa maneira, a enunciação no processo de comunicação e interação social, realizada pela mídia como produtora de informação demonstra como a mídia produz e reproduz através do discurso, que utiliza fragmentos da realidade, seja para a transmissão de cultura, seja para influir ideologicamente na formação de opinião pública, ou seja, o signo linguístico está sujeito a qualquer tipo de mudança, devendo ser levado em consideração a situação, o contexto e o sentido que trazem um novo valor ao signo, afetando a sua significação no processo social da linguagem.

No dizer de Bakhtin (2002), através da enunciação, a interação verbal é realizada como fenômeno social. Ele entende que a interação verbal pode ser 
resumida sob o termo discurso, seja no plano oral ou no plano escrito. Ele valoriza o ato de fala, a enunciação, e afirma sua natureza social: "[...] a fala está indissoluvelmente ligada às condições de comunicação, que por sua vez, estão ligadas às estruturas sociais" (BAKHTIN, 2002, p. 14). Em outras palavras, Bakhtin (2002) sustentou que as leis do objetivismo abstrato, orientação do pensamento filosófico-linguístico da proposta saussuriana, incorrem no equívoco de separar a língua de seu conteúdo ideológico por postularem que as únicas articulações a que os signos lingüísticos se submetem ocorreriam, estritamente, entre eles próprios no interior de um sistema fechado. Com vistas à superação de tal equívoco, Bakhtin (2002) apresenta o meio social como o centro organizador da atividade lingüística, refutando a identidade do signo como mero sinal e desvencilhado do contexto histórico:

O elemento que torna a forma lingüística um signo não é sua identidade como sinal, mas sua mobilidade específica; da mesma forma que aquilo constitui a decodificação da forma lingüística não é o reconhecimento do sinal, mas a compreensão da palavra em seu sentido particular, isto é, a palavra por um contexto e uma situação precisos, uma orientação no sentido da evolução e não do imobilismo (BAKHTIN, 2002, p.94).

Pêcheux (1996) também recusa completamente a concepção da linguagem que a reduz a um instrumento de comunicação de significações que existiriam e poderiam ser definidas independentemente da linguagem, isto é, "informações". Esta teoria ou concepção da linguagem é, para ele, uma ideologia cuja função nas "ciências humana e sociais" é justamente mascarar sua ligação com a prática política, obscurecer esta ligação e, ao mesmo tempo, colocar estas ciências no prolongamento das ciências naturais.

Nessa ótica a palavra passa a ser um lugar privilegiado para a manifestação da ideologia, pois aquela é produto da interação social, sendo caracterizada assim pela sua plurivalência, ou seja, cada enunciado produz 
alterações no seu sentido/significado dependendo do contexto que é produzido, para que tenha uma relação de significação entre os interlocutores.

Nessa perspectiva, fica evidente que uma linguística imanente que se
limite ao estudo interno da língua não poderia dar conta do seu objeto.
É necessário que ela traga para o interior mesmo do seu sistema um
enfoque que articule o linguístico com o social, buscando as relações
que vinculam a linguagem à ideologia. Sistema de significação da
realidade, a linguagem é um distanciamento entre a coisa representada
e o signo que a representa. E é nessa distância, no interstício entre a
coisa e sua representação sígnica que reside o ideológico (BRANDÃO,
1998, p.10).

Maingueneau (1997, p. 55), analisando as idéias bakthinianas, diz que para interpretar qualquer enunciado, é necessário relacioná-lo a muitos outros, "pois cada gênero de discurso tem sua maneira de tratar a multiplicidade de relações interdiscursivas". Nessa ótica a palavra passa a ser um lugar privilegiado para a manifestação da ideologia, pois a palavra é produto da interação social, sendo caracterizada assim pela sua plurivalência, ou seja, cada enunciado produz alterações no seu sentido/significado dependendo do contexto que é produzido, para que tenha uma relação de significação entre os interlocutores.

Partindo da afirmação de Orlandi (2001, p.38) de que "todo dizer é ideologicamente marcado", verifica-se que a ideologia materializa-se, sob a forma de texto. A ideologia, que caracteriza um discurso diferenciando-o de outros, pode ser observada em um texto através dos sentidos produzidos em decorrência da escolha das palavras empregadas, da disposição das mesmas nos enunciados, da (re)significação a que são submetidas. Estes aspectos são inerentes à construção de sentidos e a formações ideológicas que, historicamente, implicam formações discursivas. Sendo assim, ao escrever uma informação, o autor está contribuindo na formação de opinião pública, ao fazer isso está, na verdade, semantizando os discursos das fontes e, a partir deles, produzindo novos enunciados. Então, a ideologia apresenta-se 
[...] como um sistema lógico e coerente de representações e de normas ou regras que indicam e prescrevem aos membros da sociedade o que devem pensar e como devem pensar, o que devem valorizar, o que devem sentir, o que devem fazer e como devem fazer (CHAUÍ, 2006, p.113).

Para Gregolin (2001) as idéias não existem desvinculadas das palavras, a linguagem é um dos lugares onde se materializa a ideologia. Sendo assim, podemos perceber que as informações transmitidas para nós, receptores, de uma maneira bastante intencional, ora para tentar amenizar uma situação, ora para agravá-la ainda mais, ou seja, fica claro que por detrás de qualquer texto, seja ele escrito ou falado, existe uma ideologia subjacente, o que acaba por deixar a informação com um caráter de parcialidade. Dessa maneira, fica evidente que a ideologia assume o papel de "instrumento de dominação de classe porque a classe dominante faz com que suas ideologias passem a ser ideias de todos" (CHAUÍ, 2006, p.105).

Através do discurso, as ideologias podem se perpetuar, sofrer transformações, podendo ainda surgir novas formações ideológicas concomitantes ao aparecimento de novos grupos sociais, de novas formações discursivas. Verifica-se, portanto, que uma sociedade, tomada de maneira genérica, é mesclada por diferentes ideologias próprias aos diferentes discursos socialmente produzidos. Essas ideologias utilizam diversas formas de persuadir a sociedade através de veículos midiáticos apresentando o dito e não dito, em outras palavras, “[...] a ideologia se materializa nos atos concretos, assumindo com essa adjetivação um caráter moldador das ações" (BRANDÃO, 1998, p. 23).

O discurso, por sua vez, também é determinado por coerções ideológicas, por isso afirma-se que ele materializa as representações ideológicas. As ideias, as representações, não existem fora do cenário linguísticos e assim as formações 
ideológicas ganham existências nas formações discursivas, sendo assim, a ideologia investe a linguagem de várias maneiras em vários níveis.

Uma formação ideológica deve ser entendida como a visão de mundo de uma determinada classe social, isto é, um conjunto de representações, de ideias que revelam a compreensão que uma dada classe tem do mundo. Como não existem ideias fora dos quadros de linguagem, entendida no seu sentido amplo de instrumento de comunicação verbal ou não-verbal, essa visão de mundo não existe desvinculada da linguagem. Por isso, a cada formação ideológica corresponde uma formação discursiva que é um conjunto de temas e de figuras que materializa uma dada visão de mundo. Essa formação discursiva é ensinada a cada um dos membros de uma sociedade ao longo do processo de aprendizagem linguística (FIORIN, 2001, p. 32).

Dessa maneira, como nos ensina Foucault (1999), o discurso é o local onde se travam as lutas pela manutenção do poder. Não é o ambiente de neutralidade ou transparência, mas lugar de disputa, de visibilidade, de exercício de poder que usa como um dos seus meios de propagação a mídia.

\subsection{Futebol e suas dimensões sociais}

O Futebol no Brasil tem assumido um papel que vai além de uma simples modalidade esportiva, configurando-se como um fenômeno social. Pois, atingiu o status de maior esporte nacional devido ao fomento do Estado, a grande veiculação nas mídias. Isso faz com que milhares de pessoas se identificam com a prática dessa modalidade que desperta diferentes emoções. Por isso, o futebol requer uma análise que leve em consideração os seus múltiplos aspectos e perspectivas para podermos compreender melhor esse fenômeno.

Historicamente, é possível percebê-lo por duas perspectivas: enquanto meio de transmissão ideológica e enquanto um importante elemento da cultura 
brasileira. Nesta pesquisa buscamos estabelecer uma reflexão a respeito do futebol enquanto manifestação cultural e, em alguns momentos históricos, como meio de transmissão ideológica. Através deste estudo, foi possível perceber que o futebol nos fornece subsídios para que possamos ter um melhor entendimento das formas de organização e das relações que permeiam a sociedade brasileira.

A preocupação de entender como ocorre a apropriação do futebol tem sido intensamente estudada e se encontram muitos interesses que estão relacionados a ele. Segundo Pires (2000), tais interesses podem ser claramente identificados através de várias abordagens, como a funcionalização, a sociabilização, a ideologização, a mercadização e a espetacularização do esporte.

Recortando o esporte, no caso o futebol, através de qualquer uma dessas abordagens, pode-se a chegar uma reflexão crítica em relação a esse fenômeno social, sem, contudo, perder de vista a interpenetração dessas abordagens. Tendo claro que o futebol pode ser visto através de enfoques diferentes, optamos neste trabalho abordá-lo através da perspectiva: enquanto meio de transmissão ideológica, sendo a mídia o principal canal para essa veiculação ideológica, neste estudo especificamente através dos discursos que tratam sobre o futebol.

Atualmente, o futebol é o esporte mais popular do mundo. Em praticamente todos os países do mundo ele é praticado e possui ligas e confederações (BELLOS, 2003). São bilhões de torcedores em todo o planeta, que torcem pelos seus clubes e por suas seleções nacionais. Também percebemos que tal esporte é parte essencial na construção da identidade das pessoas e dos diversos grupos, a exemplo disso, hoje vemos as enormes torcidas dos clubes espalhadas pelo mundo que se juntam, e de certa forma se identificam, formando um grupo social. Infelizmente, como é comum entre diferentes grupos identificados com objetos diferentes, a situação descamba para a violência. 
Claro, que tal violência não tem origem apenas na rivalidade futebolística, mas sim em outros fatores, como os problemas sociais, étnicos e até religiosos.

Bauman (2005) define identidade como uma autodeterminação. Para ele, as identidades comumente referem-se às comunidades como sendo as entidades que as definem. A essência da identidade constrói-se em referência aos vínculos que conectam as pessoas umas às outras e considerando-se esses vínculos estáveis. Hall (2006) apresenta o conceito do que denomina "identidades culturais" como aspectos de nossas identidades que surgem de nosso "pertencimento" a culturas étnicas, raciais, linguísticas, religiosas e, acima de tudo, nacionais.

Como sabemos, o futebol está inserido na sociedade brasileira e também dentro de cada brasileiro, mesmo daquele que não gosta do esporte nem tem um time que prefira mais, no entanto sempre torce pela seleção nacional na Copa do Mundo. Desde pequeno todo cidadão brasileiro conhece o futebol, e começa a se inteirar com ele. Na condição de elemento central na cultura brasileira, o futebol tem sido capaz de gerar objetos marcantes, ou seja, o futebol no Brasil, dentro do contexto esportivo, é que tem recebido maior atenção, isso se explica principalmente pela popularidade alcançada por esse esporte no contexto mais amplo da sociedade brasileira.

O futebol tem-se identificado com a cultura brasileira, principalmente no que se refere à subjetividade de suas relações, ao que acontece dentro de um campo de futebol, como as transgressões das regras estabelecidas, da ordem e da desordem, da aproximação que o futebol faz dos torcedores com a realidade festiva do prazer e do lazer, que representam momentos de paixão e de alegria. A identificação do povo com o futebol só acontece porque ele consegue apresentar essas características, a identidade. 
O futebol brasileiro visto como uma prática social, também se constitui num meio pelo qual os indivíduos expressam determinados sentimentos... o fato de torcer por um time mesmo quando esse não ganha títulos durante muitos anos pode ser vivido como um teste de fidelidade. Suportar as gozações de torcedores contrários após uma derrota põe à prova a paixão pelo time, mesmos nos momentos difíceis. Vencer um jogo contra um time tecnicamente mais forte reaviva a crença em um ser superior que realiza milagres (DAÓLIO, 1997, p. 122).

O futebol no Brasil assim como, o samba, a fauna e a flora nacional também é um componente marcante da Identidade nacional, é só observar como este esporte se insere na sociedade brasileira. Pessoas anônimas passam a ser conhecidas do dia pra noite por terem feito o gol ou perdido o gol do título; Pessoas com menos poder aquisitivo vêem no esporte uma grande chance de ascensão social, ou seja, através do futebol podem freqüentar espaços e consumir o mesmo que aquelas pessoas que tiveram melhores oportunidades de estudo na vida; A mistura de raças muito presente na prática da modalidade, porém ultimamente com episódios de racismo, voltando a velha pergunta: A sociedade brasileira ainda é racista ?; A ginga do brasileiro que encontra sempre um jeito pra driblar a marcação dos adversários, fazendo nos lembra do velho "jeitinho brasileiro"; Sem falar nas palavras como: raça, garra, determinação tão presentes no cotidiano dos brasileiros como se a cada dia fosse uma partida e pra vencermos será necessário ter essas palavras em mente; E pra finalizar, destacamos os empréstimos lingüísticos provenientes do futebol e que estão mais que presentes nas falas dos brasileiros como aponta Milan (1998, p.18).

Sentindo-se querido ou cobiçado, o brasileiro garante que o outro lhe "deu bola".Tendo enganado o opositor, vangloria-se com o verbo "driblar". Tendo se enganado,confessa que "pisou na bola". Se excluído da atividade ou grupo, está "fora da jogada". Se em dificuldade, mas com intenção de vencer, "vai derrubar a barreira" e então clama por "bola pra frente". Caso, no entanto, abra mão da luta, anuncia que "tira o time de campo". Ameaça aposentar-se "pendurando as chuteiras", seja homem ou mulher, presidente da República ou cantora de sucesso. 
O futebol seria assim um espaço onde a sociedade simbolicamente se expressa, manifesta-se, deixando descobrir-se. Da Matta (1982) afirma que o futebol trata-se de um enorme espelho que reflete a sociedade em que vivemos. "O futebol praticado, vivido, discutido e teorizado no Brasil seria um modo específico, entre tantos outros, pelo qual a sociedade brasileira fala, apresenta-se, revela-se, deixando-se, portanto descobri-se" (DA MATTA, 1982, p. 21). Sendo assim, o futebol ideologizado, falseia o ideológico que mascara a realidade de uma sociedade socialmente desigual, dos interesses econômicos e políticos, utilizando a mídia como principal meio para essa veiculação, sempre à mira de lucrar e manipular os sentimentos populares por parte do poder instituído.

Dessa forma, Da Matta (1982) revela que o principal papel do futebol é desviar a atenção do povo, ou seja, somente a classe dominante sabe o real papel do futebol na sociedade (que o utiliza como ópio das massas) e os críticos da sociedade. A massa continua na inércia, na escuridão, na embriaguês, incapaz de perceber seu sistemático engano.

No que diz respeito aos aspectos simbólicos, o futebol não é ideológico em si mesmo, mas se torna, na medida em que é utilizado em um determinado contexto social no sentido de transparecer valores e verdades de uma determinada concepção que se pretende tornar hegemônica. "[...] As formas simbólicas, ou sistemas simbólicos, não são ideológicos em si mesmo: se eles são, e quando são ideológicos depende da maneira como são utilizados e entendidos em contextos sociais específicos" (THOMPSON, 1995, p.17).

Apesar dessa riqueza simbólica que se estabelece no e através do futebol, este já é visto, não apenas como uma forma de manifestação cultural que está inserido dentro do imaginário coletivo, observa-se que, através da mídia e com a popularização e a massificação, o futebol passa a representar, um veículo de 
propaganda no sentido de afirmar a ideologia e o pensamento político da classe dominante representada pelo governo institucional. A concepção de ideologia em que pretendemos nos apoiar no presente trabalho é a defendida por Thompson (1995, p.16) quem diz que "[...] o futebol foi utilizado de forma a prestar uma sólida contribuição no sentido de reforçar a construção de uma identidade nacional".

Dessa maneira, a análise da ideologia pode ser vista como uma parte integrante de um interesse mais geral ligado às características da ação e da interação, às formas de poder e de dominação, à natureza da estrutura social, à reprodução e à mudança social, às qualidades das formas simbólicas e a seus papéis na vida social que atendem a interesses daqueles que desejam se perpetuar no comando da sociedade.

Sendo assim, o futebol seria um legítimo representante da cultura brasileira, pois deixa transparecer, de maneira significativa, na sua subjetividade determinadas relações que se estabelecem no seio da sociedade como: paixão, sofrimento, identidade nacional, ascensão social, glamour, fama, dinheiro, status e que são vistas como uma possibilidade que se diferencia da rotina diária de grande parte da população, oscilando entre o real e o desejado. 


\section{DECISÕES METODOLÓGICAS}

A metodologia da pesquisa deve ser entendida como um conjunto detalhado e seqüencial de métodos e técnicas científicas a ser executado ao longo da pesquisa, tal modo que se consiga os objetivos inicialmente propostos. Em toda pesquisa é fundamental ao investigador definir os encaminhamentos metodológicos, pois, tão importante quanto saber o quê pesquisar está como pesquisar. Segundo Demo (1998) há uma preocupação com o método porque é sinal de competência definir quais serão os pressupostos que sustentarão o trabalho teórico e empírico de uma pesquisa.

Outra autora que destaca a importância da questão metodológica à pesquisa é Minayo (1994) a qual salienta que, em se tratando de pesquisa qualitativa, os métodos escolhidos para coleta e análise dos dados não podem abrir mão, ou seja, desconsiderar a conjuntura social, política, econômica na qual o problema de pesquisa está inserido. Devemos manter a atenção e proximidade com a realidade, nesse sentido a autora diz que:

A metodologia pode ser compreendida como o caminho do pensamento e a prática exercida na abordagem da realidade. Portanto, embora seja uma prática teórica a pesquisa reúne pensamento e ação. Ou seja, nada pode ser intelectualmente um problema, se não tiver sido, em primeiro lugar, um problema da vida prática. As questões de investigação estão, portanto, relacionadas a interesses e circunstâncias socialmente condicionadas. (MINAYO, 1994, p.16-17)

Com relação ao tipo de pesquisa, foi utilizada neste trabalho, uma pesquisa de campo numa perspectiva epistemológica descritiva interpretativa, tratando o fenômeno estudado em uma dimensão qualitativa visto toda a complexidade da problemática do discurso midiático televisivo. A abordagem qualitativa torna-se essência para a pesquisa social "[...] na perspectiva de que a realidade social 
também se expressa por discursos devendo seus significados ser interpretados numa perspectiva qualitativa". (SILVA, 2008, p.143)

A abordagem qualitativa de pesquisa é entendida por Godoy (1995) como capaz de estudar fenômenos que envolvem seres humanos e suas intrínsecas relações sociais, estabelecidas em diversos ambientes. Para Goellner (2010, p. 1):

A pesquisa qualitativa, muito mais do que um conjunto de procedimentos organizados para representar os fatos, os fenômenos, enfim, a realidade, constitui-se, dado o seu desenvolvimento tanto no Brasil quanto em âmbito internacional, em um campo de estudos complexo que ultrapassa as fronteiras disciplinares, comunidades de investigadores e áreas de conhecimento, adequando-se ao estudo de problemas de conhecimento científico em inúmeros setores da atividade humana.

Desta forma, este trabalho também se caracteriza como uma pesquisa descritiva, porque visa observar, registrar, analisar e correlacionar fenômenos, ou seja, à medida que identifica e descreve a ocorrência do fenômeno objeto da pesquisa. Segundo Godoy $(1995$, p.62) a pesquisa qualitativa tem como uma de suas propriedades o caráter descritivo que:

Aparecem sob a forma de transcrições de entrevistas, anotações de
campo, fotografias (...) e vários tipos de documentos. Visando a
compreensão ampla do fenômeno que está sendo estudado, considera
que todos os dados da realidade são importantes e devem ser
examinados. O ambiente e as pessoas nele inserido devem ser olhados
holisticamente: não são reduzidos a variáveis, mas observados como
um todo.

Para o desenvolvimento desta investigação utilizamos como plano metodológico a pesquisa de campo destinada a observar e analisar parte dos cotidianos escolares de jovens do primeiro ano do ensino médio de uma Escola pública de São Luís - MA, especificamente, em suas aulas de Educação Física. 
Optamos em realizar a pesquisa na Cidade de São Luís, por estar localizada no nordeste brasileiro, mais precisamente no Estado do Maranhão que tem o Índice de Desenvolvimento Humano (IDH) de 0,639 e que estar ocupando a penúltima colocação no ranking nacional. (ATLAS..., 2014). Vale ressaltar, que o IDH é um índice composto por três indicadores de desenvolvimento humano: vida longa e saudável (longevidade), acesso ao conhecimento (educação) e padrão de vida (renda). Sendo assim, entendemos que com esse trabalho podemos contribuir para que as escolas do Maranhão possam reverter esse atual cenário.

A pesquisa também foi conduzida pela observação participante que é caracterizada como o processo que se realiza no contato direto do pesquisador com o objeto/campo de estudo, com o propósito de obter informações sobre a realidade observada. Nele, segundo Becker (1994, p.47). O observador participante coleta dados através de sua participação na vida cotidiana do grupo ou organização que estuda, além de estabelecer interpelações com uma parte ou com todos os participantes da observação e descobre as interpretações que eles têm sobre os acontecimentos que observou.

Um passo importante para a sistematização da observação perpassa a delimitação do objeto de estudo, pois, quando sabemos o que observar, podemos captar melhor os fenômenos. Desse modo, na observação participante a experiência como professor de Educação Física em escolas contribuiu para refletir e compreender melhor determinados fenômenos observados, além de auxiliar na seleção daquilo que era realmente relevante de ser observado e o que não é tão importante para o trabalho de pesquisa.

Além de saber o que vamos observar e delimitar nosso foco de pesquisa é fundamental também definir qual será o grau de participação do observador na 
pesquisa, bem como todos os procedimentos por ele utilizados como a duração das observações, condições materiais e espaciais, número de participantes, etc. Conforme Bogdan e Biklen (1994, p.150), “[...] é necessário calcular a quantidade correta de participação e o modo como se deve participar, tendo em mente o estudo que se propôs elaborar.".

Faremos uso de diário de campo Cruz Neto (1994, apud MENDES, 2008) define o diário de campo como um instrumento que recorremos em qualquer momento da rotina do trabalho que estamos realizando e que serve de um —amigo silencioso, não podendo ser subestimado quanto à sua importância. Ainda, é nele que podemos colocar nossas percepções, angústias, questionamento e informações que não são obtidas através da utilização de outras técnicas, aplicaremos questionários que "[...] tem por objetivo o conhecimento de opiniões, crenças, sentimentos, expectativas, situações vivenciadas" (GIL, 1995, p.124). Também realizaremos conversas com grupos de discussões os quais "[...] define como uma técnica de pesquisa que coleta dados por meio das interações grupais ao se discutir um tópico especial sugerido pelo pesquisador" (GONDIM, 2013, p.3), no intuito de refletir sobre assuntos vistos durante um processo de pesquisa, para avaliar conceitos e identificar problemas, entendendo as reações dos indivíduos em relação ao que está sendo pesquisado. O grupo de discussão teve como ponto de partida as matérias do programa Globo Esporte/ RJ que foram veiculada pós-jogo da seleção brasileira de futebol na Copa de 2014.

Optamos pela escolha do Programa Globo Esporte/ RJ, pois em um estudo piloto realizado na escola Cintra tivemos como resultado uma significativa audiência e aceitação desse programa, ou seja, a maioria dos alunos pesquisados se informa por esse veículo midiático. Constatamos esse fato na aplicação de um 
questionário de consumo de mídias.

Utilizamos como técnica de captação de discursos um gravador, pois conforme Triviños (1987) irá facilitar em uma possível retomada a análise dos discursos dos sujeitos da pesquisa. Desse processo, elegeremos alguns temas recorrentes para uma análise mais profunda, dos quais, surgirão os eixos temáticos que serão discutidos na dissertação de mestrado sob a luz do quadro teórico da Análise do Discurso (AD) de linha francesa.

Ao final, após o estudo bibliográfico e a pesquisa de campo, todas as informações encontradas foram organizadas e selecionadas para a análise sistemática, amparada na fundamentação teórica que sustenta a investigação. Tudo isso, com intuito de responder aos questionamentos levantados e elaborar uma dissertação que possa atender às exigências do curso de Mestrado em Educação Física/UnB e oferecer subsídios de pesquisa para os profissionais interessados na temática. 


\section{PRELEÇÃO}

Partimos de uma experiência com alunos do $1^{\circ}$ ano do ensino médio, de uma escola pública de São Luís, capital do Estado do Maranhão. Vale ressaltar, que essa experiência está de acordo com o Plano Político Pedagógico da escola, esse que, por muitas vezes, é ignorado por pesquisadores. O plano da escola traz em seu texto que a escola deve está atenta as novas demandas sociais, dentre elas destaca a relação com a mídia. Utilizamos em nosso trabalho a TV como objeto de estudo, pois essa mídia continua sendo o principal meio de comunicação em que as pessoas se mantêm informadas, ou seja, a escola deve e precisa tratar esse fenômeno de forma crítica e propositiva, enfatizando a necessidade de uma análise minuciosa entre as diferentes linguagens e conteúdos trazidos nessa mídia nas práticas educacionais na tentativa constante de elevar a capacidade do ser humano.

Trazemos como objeto a ser debatido a Copa do Mundo de Futebol da FIFA/2014, que foi realizada no Brasil, como um importante momento para tecermos algumas reflexões acerca das relações que vêm se estabelecendo entre esporte e mídia e, a representatividade de tais relações no contexto escolar, por ser o Brasil o país sede e sua extrema relação com o esporte em questão.

A Copa de 2014 de fato teve início em 2013 com um ensaio denominado como Copa das Confederações. Analisando esse evento na perspectiva apenas esportiva podemos salientar que a seleção brasileira teve um ótimo desempenho vencendo a competição de forma invicta, fazendo aumentar a confiança dos brasileiros na conquista do hexacampeonato mundial. Por outro lado, e concomitantemente a esse primeiro teste vieram às grandes manifestações que se 
disseminaram em todo o país. Manifestações estas que tiveram ampla cobertura dos veículos midiáticos e que em suas redações traziam informações que influenciaram de forma significativa no modo de pensar e agir dos brasileiros. Grupos organizados como: Entidades estudantis, Sindicatos de trabalhadores, ONGs e até mesmo os badalados "Black Bloc" traziam em suas pautas melhores condições de vida para toda população, além de alertar para os gastos descontrolado do dinheiro público e juntamente as suas reivindicações um requinte de vandalismo. Para os manifestantes o Estado já não atendia a contento os principais anseios da sociedade.

Nesse sentido e dentre outras razões, dizemos que o biênio 2013-2014 foi um excelente momento histórico para análises, discussões e reflexões sobre as possíveis representações esportivas geradas no cotidiano social do País. Bem como, os sentidos e significados que são atribuídos ao esporte por meio do discurso midiático em tempos de superexposição de um de nossos mais valorosos "produtos" nacionais: o esporte, em especial, o futebol.

Em meio a muitos discursos que tratam sobre o futebol, veiculadas na mídia durante a Copa do Mundo de 2014, alguns se mostraram bastante pertinentes para explorarmos nesse estudo, principalmente, aqueles que surgem no interdiscurso entre a mídia (TV) e os alunos, é essa interação entre emissor/receptor e vice-versa que servirá de objeto para a nossa análise propriamente dita.

A utilização do discurso dos alunos sendo relacionado ao discurso veiculado na mídia como objeto de análise, nos dá plena possibilidade à nossa pesquisa de partir da materialidade dos enunciados selecionados encontrar, nessa materialidade, vestígios de um confronto de forças que está muito além do enunciado, que centra seus embates nos domínios da sociedade pós-moderna e 
sua problemática social, cultural, política e econômica.

Essas reflexões permitem afirmar que a língua se insere na história para produzir sentidos, o estudo do discurso toma a língua materializada em forma de texto, tendo o discurso como objeto, a análise destina-se a evidenciar os sentidos do discurso tendo em vista suas condições sócio-históricas e ideológicas de produção. As condições de produção compreendem fundamentalmente os sujeitos e a situação social e as palavras têm sentido em conformidade com as formações ideológicas em que os sujeitos se inscrevem.

Partindo da premissa de que os meios de comunicação não podem mais ser concebidos como manipuladores e nem o receptor pode mais ser entendido como passivo e passível de quaisquer tipos de influências, tentamos em nosso estudo abordar a mídia como um instrumento cotidiano na vida das pessoas, cuja introdução se iniciou durante o século passado por meio das evoluções tecnológicas e que faz parte integral dos conflitos que regem esse cotidiano, desde o consumo de determinado alimento até a formação cultural, política e, por que não arriscar, ideológica do homem contemporâneo.

Consideramos então, que problematizar o que parece evidente é uma maneira de não tomar o que é de fato socialmente "construído" (como a representação midiatizada da "realidade") por "dado" da natureza. Só dessa maneira iremos perceber que os discursos ressaltam alguns significados, ocultam outros, incorporam significados correntes em alguns grupos e os ampliam para toda a sociedade, entre outras operações, nas quais se manifesta o potencial de veiculação de ideologia através da mídia, "naturalizando" representações sociais e operando no sentido da manutenção de uma dada relação de forças no interior da sociedade. 
É preciso sair do especificamente lingüístico, dirigir-se a outros espaços, para procurar descobrir, descortinar, o que está entre a língua e a fala e fora delas, ou seja, para compreender de que se constitui essa exterioridade a que se denomina discurso. Sendo assim, devemos observar que a interdição dos discursos que tratam sobre o futebol trabalha a favor dos interesses dos setores conservadores que querem permanecer no poder.

Com isso, dizemos que discurso implica uma exterioridade à língua, encontra-se no social e envolve questões de natureza não estritamente lingüística. Referimo-nos a aspectos sociais e ideológicos impregnados nas palavras quando elas são pronunciadas, assim observamos, em diferentes situações de nosso cotidiano, sujeitos em debate e/ou divergência, em oposição acerca de um mesmo tema. As posições em contraste revelam lugares socioideológicos assumidos pelos sujeitos envolvidos, e a linguagem é uma forma material de expressão desses lugares. Vemos, portanto, que o discurso não é a forma é a linguagem em si, mas precisa dela para ter existência material e/ou real.

Analisar o discurso implica interpretar os sujeitos falando, tendo a
produção de sentidos como parte integrante de suas atividades sociais.
A ideologia materializa-se no discurso que, por sua vez, é
materializado pela linguagem em forma de texto (FERNANDES,
2007, p. 21).

Dessa maneira, só através de uma análise minuciosa dos discursos que tratam de futebol, percebemos os diferentes discursos materializados nesse tempo e explicitaremos o entrecruzamento dos aspectos sociais, históricos e ideológicos na linguagem, a partir dos quais apontaremos as diferentes vozes constitutivas do sujeito discursivo para respondermos a seguinte pergunta: Como se dá a recepção ao discurso midiático acerca da Copa do Mundo de 2014, por parte dos jovens escolares? 


\section{PRÉ-JOGO}

\subsection{Caracterizando o campo - a escola}

O lócus da pesquisa foi a Escola Cintra - Centro de Ensino Unificado Rio Anil - localizado. No bairro do Anil, um dos bairros mais antigos da cidade de São Luís - Ma. O atual bairro do Anil começou a ser povoado ainda no século XIX e foi durante anos o principal portão de entrada da capital com o continente. Já foi considerado município do estado do Maranhão, depois distrito de São Luís e desde a década de 1960 é considerado como bairro. Começou a ganhar status de bairro na década de 1940, quando a Fábrica de Tecido existia nas margens do Rio Anil.

Quando a fábrica de tecido chegou a bairro na década de 1893, só conseguia acesso a parte da fábrica através de canoas. Não havia transporte até o centro da cidade, nem abastecimento de água nas casas, a iluminação era clandestina e as ruas não tinham infra-estrutura alguma.

Somente na década de 1960 que o bairro começou a ser visto como bairro. A principal Avenida do Anil ganhou pavimentação e foram construída pontes de concreto ligando a parte que era isolada, até a Avenida Casemiro Júnior. Já nos anos 70 a fábrica de tecidos já havia falido e novos conjuntos habitacionais foram construídos ao longo da Avenida Santos Dumont. Na década de 1990, no governo de Edison Lobão, quando o mesmo era governador do Estado do Maranhão, mandou construir no local da extinta fábrica, a Fundação Nice Lobão, centro de ensino estadual, que ia do jardim de infância até o ensino médio, hoje a escola é considerada como uma das maiores do estado. O bairro tem recebidos 
novos empreendimentos imobiliários, o que tem cada vez mais valorizado o bairro. O Anil é sede do INCRA - Instituto de Colonização e Reforma Agrária, do Instituto Divina Pastora, uma das melhores escolas particulares do estado, da Igreja Nossa Senhora da Conceição, da Faculdade Santa Terezinha, do $4^{\circ}$ Juizado Criminal e dos Grêmios Recreativo Litero Português e Jaguarema, ambos desativados desde os anos 90.

A escola Cintra funciona em três turnos, que vai da educação infantil até o ensino médio; possui 02 anexos, totalizando 56 salas, 03 quadras poliesportivas; cerca de 8000 mil alunos; 458 professores sendo 30 de Educação Física; oferece cursos profissionalizantes (padaria, artes manuais, corte e costura, pintura em tecidos, cabeleireiro, design de sobrancelhas, depilação, horta e dança).

\subsection{Caracterizando o campo - os professores de Educação Física}

No ano de 2011, os professores de Educação Física fizeram um movimento para que as aulas da disciplina deixassem de ocorrer nos contra turnos escolar por vários motivos, dentre eles podemos destacar: excesso de faltas; aumento da despesa da família, etc.

No ano de 2012 os professores de Educação Física conquistaram essa vitória, porém, devido à grade de horários apertada, as aulas de Educação Física que eram $02 \mathrm{~h}$ por semana passou a $01 \mathrm{~h}$ só, o que ocasiona um problema na metodologia das aulas. Todavia, não houve o mesmo movimento para manter a carga horária de 02 horas semanais. Para que realizássemos este estudo foi necessário que a professora titular da disciplina fizesse uma negociação nos seus horários. 
A escola Cintra no seu corpo docente de Educação Física possui professores especializados em diversas modalidades: futsal; vôlei; handebol; futebol; xadrez; basquete; atletismo; natação; ginástica rítmica e jiu-jítsu. Existe certo embate entre os professores que atuam nessas modalidades e os que atuam no ensino regular. Os docentes que atuam na Educação Física escolar consideram que eles trabalham mais, têm atividades para corrigir, diários para preencher e provas para elaborar. Enquanto, os "treinadores" têm uma carga horária menor, não freqüentam as reuniões, pouco aparecem na escola, além de utilizarem outros espaços fora da escola que são mais convenientes a eles para realizarem seus treinamentos.

Outro fator conflitante na escola é o espaço físico, como são muitas turmas os professores de Educação Física acabam dividindo quadra chegando a ter 3 turmas de 40 alunos em só local. Outra observação importante detectada, é que os alunos da noite têm aulas de Educação Física somente de forma teórica, não vivenciam a especificidade da disciplina por a escola não ter espaço suficiente, o que ocasiona uma grande evasão nas aulas. As quadras da escola no período noturno é utilizada para os treinamentos das modalidades que representarão a escola nos jogos escolares maranhenses. O coordenador da Educação Física nos informou que existe um cronograma de aulas teóricas e práticas, o que acontece é que alguns professores por comodidade não cumprem o combinado. Ressaltou também, que o problema da noite já está sendo estudado.

Além da disputa por espaço físico entre os professores, também se apresenta uma "corrida" pelo material das aulas (bolas, cones, corda, bastão, rede de vôlei, etc.) quem chega primeiro fica com o material. Segundo os professores, em toda reunião é o que mais se cobra, porém pra Direção, o material esportivo não parece ser prioridade. Os professores que não querem participar da "corrida" 
pelo material esportivo acabam comprando o seu próprio material para trabalhar de forma digna.

Quanto à formação dos professores, 80\% têm especialização, sendo que $40 \%$ destes têm especialização em Educação Física. Os professores disseram que o Estado não estimula a qualificação docente, não tem um plano de cargos e carreiras interessante, por isso não pretendem fazer mestrado e doutorado. Também observamos que a maioria dos professores trabalham em mais de uma escola para poder comer, descaram. A média de idade dos professores é de 41 anos. A maioria são mulheres. Outra curiosidade é que nenhum professor de Educação Física tem seus filhos matriculados na escola. Segundo eles, acreditam no ensino público, entretanto vêem que a falta de acompanhamento de alguns pais fazem com que os filhos se tornem influencias negativas no processo ensino aprendizagem.

\subsection{Caracterizando o campo - os alunos pesquisados}

Acompanhamos durante a pesquisa uma turma é de $1^{\circ}$ ano do Ensino Médio do turno matutino composta por 45 alunos. Os alunos sua maioria moram nas adjacências da escola. Têm idade entre 15 e 17 anos. Têm renda familiar em média de 03 (três) salários mínimos. São 70\% de cor preta e parda. As meninas são maioria na classe. Estudam na escola por não terem condições de estudar numa escola melhor. 50\% da turma fizeram o Ensino Fundamental da na própria escola pesquisada. Os pais dos alunos têm o ensino médio completo. 30\% dos alunos têm pelo menos uma reprovação no currículo. Os alunos têm melhor rendimento nas matérias da área de humanas. 
Com a aplicação de um questionário pudemos ter informações que não foram reveladas pelos alunos durante os primeiros encontros. Todos os alunos da turma em que fizemos o estudo possuem celular, todos gostam de assistir televisão, $80 \%$ da turma tem TV por assinatura; $80 \%$ passa mais que duas horas em frente à TV; Mesmo tendo TV por assinatura 95\% afirmaram que a TV Globo é a emissora que mais assistem; 78\% se interessam por programas esportivo; $96 \%$ procuram informações acerca do futebol; $70 \%$ disseram que não se deixam influenciar pelas informações veiculadas pelos programas o qual se informam.

Por meio desses dados podemos constatar que a mídia mais consumida ainda é a televisão, pois ela utiliza recursos híbridos que fazem com que ela seja uma ferramenta eficaz na construção de opiniões, gostos e valores. Imagens, sons e discursos são elementos que interagem com o receptor, são demandas interpretativas que são negociadas a partir do conhecimento de mundo do telespectador. Este, por sua vez, já não considera sua relação com a TV conflitante, pelo contrário, busca a todo instante esse "meio" de comunicação para se sentir informado.

Ainda com base no questionário, as respostas de algumas perguntas serviram de elementos para análise como veremos a seguir. Para a pergunta:

9) Enquanto assiste aos programa, o que lhe chama mais atenção?

Os alunos em grande maioria disseram que gostam de ver os gols, os debates acerca das polêmicas que acontecem nos jogos. Porém, não analisam a forma como é feita as apresentações dos gols, como os jornalistas exploram as polêmicas, a sequência dos blocos do noticiário, o marketing apresentado nos programas esportivos. Então, percebemos que são muitos elementos que podem 
ser trabalhados nas aulas de educação física com o intuito de fazer despertar nos alunos um maior nível de criticidade sobre as informações veiculadas sobre o futebol.

Para Betti (1998) o professor, nesse contexto, deve exercer um papel de mediador entre estudantes e mídia, partindo do contexto sociocultural em que os alunos estão inseridos. Buscando sempre uma posição em relação a essa mídia e a esses estudantes, livres de preconceitos, acima de tudo buscando qualidade naquilo que é exposto aos mesmos, até porque vivemos na chamada era da informação, onde temos cada vez mais informações sobre os mais variados assuntos, e se isso for usado para a educação, a favor dela, e não contra ela, essa pode ser uma geração que terá uma perspectiva critica e diversificada das informações.

Sendo assim, é tarefa da Educação Física tentar fazer com que os estudantes tenham uma postura crítica perante esses fenômenos, evitando uma reprodução do que é visto na TV, a partir do esporte espetáculo, e buscando adaptações desse esporte dentro da escola. Dessa forma, para a escola possuir uma função emancipatória, como nos coloca Kunz (1994, p.115), o ensino deverá "[...] ser um ensino de libertação de falsas ilusões, de falsos interesses e desejos, criados e construídos nos alunos pela visão de mundo que apresentam a partir de 'conhecimentos' colocados a sua disposição pelo contexto sócio-cultural onde vivem".

11) Você acha que as informações que são veiculadas nesses programas influenciam nos seus padrões de comportamento e de consumo? Se sim, por quê?

Nessa pergunta a maioria respondeu que apenas se informa pelos programas esportivos, mas não se deixa influenciar pelas opiniões dos 
jornalistas, pois nem sempre os jornalistas estão corretos. Aqui, percebemos que as informações que lhe interessam são as tidas como verdadeiras e aquelas que vão à contramão dos seus interesses são desprezadas. Contudo, as opiniões que os alunos julgam verdadeiras estão impregnadas de ideologias que pretendem se tornarem hegemônicas. De acordo com Betti (1998) o jornalismo esportivo (comentaristas, narradores, etc.) é capaz de influenciar aqueles/as que assistem, fazendo com que aquilo que é dito torna-se muitas vezes uma verdade absoluta, e dessa forma algo incontestável.

Dessa forma, a mídia, é o lugar onde se produzem os acontecimentos sociais, isto é, ela que agenda os assuntos que fazem parte do dia-a-dia do público em geral e faz a mediação entre os demais campos sociais, entre outros fatores pertinentes. Neste sentido, somente um leitor atento a esses nuances é que pode refletir criticamente, transcendendo esses limites para efetivamente construir novos sentidos e significados. Por isso, cabe ao professor buscar elementos da cultura corporal de movimento que são constantemente explorados pela mídia como temas a ser problematizados na busca da compreensão do processo emancipatório de ensino.

14) Você acha que as informações transmitidas por essa emissora sobre a Copa do Mundo, e mais precisamente sobre o futebol geraram expectativas para as aulas de Educação Física? Se sim, por quê?

A maioria dos alunos disse que sim, pois, para eles, a Copa do Mundo mexe muito com as emoções. Segundo eles nas aulas de educação física é o momento de tentar colocar em prática tudo aquilo que se ver nos jogos. Podemos perceber que os alunos de fato tratam a aula de educação física como um laboratório em que tem a exclusiva finalidade de experimentar empiricamente aquilo visto, nesse caso pela TV. 
A tradição do fazer supera o conhecer, então, voltamos a insistir que não cabe mais no seio da escola professores que não aumentem o repertório de conhecimento dos alunos, não queremos aqui reduzir a especificidade da educação física, pelo contrário, sugerimos sim que o professor desenvolva no aluno novas habilidades motoras, o prazer pela atividade física, todavia entendemos que seja necessário romper a barreira do comodismo e buscar novas possibilidades metodológicas, pois a aula de educação física é um espaço de interação social em que professores e alunos juntos determinam novos significados para recorrentes práticas. 


\section{O JOGO}

Antes de iniciar a pesquisa passamos por momentos de dúvida, pois iremos buscar informações em um ambiente novo e que às vezes somos mal interpretados por fazer entrevista, aplicar questionários, solicitar documentos. Somos vistos como "Fiscais", pois para o entendimento da maioria iremos apontar/criticar as fragilidades da escola. Outros entendem que só iremos explorar aquele ambiente e depois sumir sem ao menos dá um retorno. São várias conotações que são atribuídas a nós pesquisadores o que nos causa insegurança e até mesmo medo.

Com base nisso, é que no caminho da escola para realizar a primeira visita, vimos conjecturando formas de abordagem aos gestores, professores e alunos. Muitas ideias surgem, porém na mesma velocidade em que surgem desaparecem pelo receio de não dar certo. Por isso, julgamos esse primeiro contato com a escola muito importante, porque começar bem a pesquisa eleva nossa autoestima fazendo com que os dados sejam captados de forma natural.

O primeiro contato foi com a diretora do Ensino Médio que nos recebeu muito bem e agilizou toda documentação de modo que eu iniciasse logo a pesquisa. Em seguida, nos dirigimos ao Departamento de Educação Física DEFIDEL, onde o gestor da mesma forma que a diretora geral nos recebeu de forma muito positiva e foi logo nos apresentando para os professores que estavam presentes para iniciarmos as primeiras conversas acerca da prática pedagógica. Aproveitando o momento fizemos logo o acordo para acompanharmos a turma acima citada no dia de sexta feira. Então ficou acordado que iria observar 05 aulas antes de iniciar o grupo de discussão. 


\section{PRIMEIRO TEMPO}

No primeiro contato com turma, a professora me passou a palavra. Eu me apresentei, depois falei da minha pesquisa, logo em seguida falei da importância da contribuição deles nesse trabalho inicial. Destaquei que não estava ali com o intuito de punir quem não quisesse colaborar, expliquei o termo de consentimento, e por último, passei o cronograma da pesquisa.

Na primeira aula em que acompanhei a turma fiquei numa postura de observador, a professora levou a turma para a quadra e começou algumas atividades referentes ao conteúdo futebol. Nessas atividades, ela trabalhou os principais fundamentos do futebol (passe, condução, chute e drible). A turma se mostrou bem participativa e a professora fazia questão de destacar que na aula dela os jogos tinham que ser misto, ou seja, não separava as atividades por gênero como é muito comum na disciplina.

Assim como um antropólogo busquei na pesquisa estranhar o familiar e me familiarizar do estranho foi aí que consegui buscar elementos para a pesquisa logo de início. Na aula da professora titular da turma pude perceber que nem todos os alunos tinham ou estava com a devida farda de Educação Física, ou pelo menos não levaram nesse dia com exceção das meninas, todos os meninos que estavam naquela aula não trajavam a farda e sim utilizavam o uniforme de grandes times de futebol. Vale ressaltar, que nenhum deles utilizava uniforme dos times brasileiros e muitos menos das equipes maranhenses. Quando tive a oportunidade de perguntar por que não usavam uniforme de times do maranhão? Tive as seguintes respostas: 
Os times daqui não têm craque ... Não dá mídia ... É muito fraco (Aluno A)

Ah professor, os grandes craques jogam fora do Brasil, no Brasil só fica os mala. (Aluno B).

Eu sou mais Cristiano Ronaldo, Messi, Neymar do que Pimentinha. (Aluno C)

A partir dessas falas podemos analisar que atualmente, o futebol parece ser o parceiro preferencial da espetacularização na mídia televisiva porque oferece, em contrapartida, o show já pronto. O cenário, o roteiro, os atores, os espectadores e até os (tele) consumidores estão antecipadamente garantidos, o que facilita a sua transformação em produto facilmente comercializado / consumido em escala global. Pires (2006, p.21), entende que "na lógica neoliberal, a própria cultura mundializada transforma-se em mercadoria padronizada e simbolicamente consumida através da mídia". Tendo o esporte como produto cultural onde o reconhecimento e anuência integral aumenta à medida que se torna cada vez mais um telespetáculo. Pozzi (1999) considera tratar-se de uma parceria indissolúvel e com tendência a crescer, vez que, se a TV populariza as modalidades, tornando-as mercadoria bem aceita no mercado mundial, também o esporte proporciona benefícios para a TV. Segundo ele,

O esporte se tornou um produto perfeito para satisfazer aos dois mercados da TV: o telespectador, que cada vez mais consome esporte (as maiores audiências da TV mundial são de eventos esportivos), e o mercado publicitário, atraído pelas grandes audiências junto aos seus públicos-alvo (POZZI, 1999, p.67)

Neste sentido, os jovens se apropriam do discurso televisivo, pois esse veiculo midiático de grande alcance não abre espaço para os times de menos expressão nacional, que é caso dos times maranhenses. Estes pequenos times, 
não têm jogadores e muito menos nos seus uniformes carregam grandes marcas para que haja interesse da grande mídia em explorar sua imagem. Deste modo, o discurso midiático preocupa-se em promover sentidos adaptadores a massa de signos sociais que reproduz implicitamente ao espetáculo esportivo teleapresentado, a mídia passa a ser a principal produtora dos sentidos e significados válidos/validados socialmente sobre esporte, ou seja, os meios de comunicação de massa, porta-vozes por excelência da nova forma de se ver no mundo, amplificam sobremaneira tais preceitos através de reprodução exacerbada dos padrões desejáveis, representada pela figura produzida de ídolos a serem copiados.

Autores como Helal (1999), defendem que o fenômeno esportivo não se sustenta na mídia sem a presença de "estrelas". Essas "estrelas" são também uma das válvulas propulsoras e mantenedoras do esporte na mídia e facilitam a própria espetacularização do fenômeno esportivo. Pela publicação de aspectos de cunho social dos atletas, a indústria midiática consegue construir imagens sociais respeitadas na figura de ídolos e heróis esportivos. Esses ídolos e heróis, que muitas vezes viram "marcas" de um nacionalismo "fabricado", fazem parte do espetáculo e não raras vezes tornam-se o próprio espetáculo. (ANTUNES, 2007)

O aluno não se percebe como parte estruturante que alimenta a lógica do capital, pois ele através da sua fidelidade financia o esporte por meio do seu consumo passivo de produtos esportivos, referentes aos anúncios publicitários que tanto tem orgulho de vestir. Nessa linha de raciocínio os grandes astros esportivos, torna-se uma combinação perfeita da imagem vencedora ao produto comercializado, tornando-se interessante para industria cultural.

Dumazedier (1979, p.10) afirma: 
[...] a peça (espetáculo esportivo) não é escrita antes de ser representada, mas sim concomitantemente; e o público, mais do que em qualquer outro espetáculo, tem a impressão de que contribui para a escrita, compartilhando, em espírito e em gesto, as esperanças e angústias dos atores.

Assim à medida que o discurso televisivo articula determinados significados aos fatos oculta outros, é construído nesse discurso uma "definição da realidade", que, dada a imensa difusão social de suas informações, tem grandes possibilidades de manter-se hegemônica, colaborando de modo ativo na manutenção da relação de forças no interior da sociedade.

Betti (2001) reforça que para além do esporte espetáculo, nasce uma nova proposta de consumo pronta e acabada para o grande público: o esporte telespetáculo, elaborado pela televisão, propiciando uma série de informações. Oportunizando ao espectador, uma realidade textual relativamente autônoma, em face de prática "real" do esporte, construída pela codificação e mediação dos eventos esportivos, efetuando uma construção seletiva e interpretativa, selecionando imagens reproduzidas pela própria televisão.

Dessa maneira, o esporte sendo transformado em espetáculo passa a ser visto de outra forma. O detalhe do esporte como: a cor da chuteira, os músculos que são recrutados no momento do chute, a velocidade da bola, ou até mesmo a mordida de um atleta, vale muito mais do que o sentido e significado do jogo, ou seja, esses artifícios produzidos pela TV influenciam boa parcela da população gerando novos valores, determinando atitudes dos consumidores diante o fenômeno esportivo. Eco (2004) corrobora destacando que a TV surge com a finalidade de instruir gostos e propensões, estabelecendo novas necessidades e tendências no campo esportivo. Neste sentido, a indústria cultural - termo criado pelos teóricos Theodor Adorno e Max Horkheimmer (1985) que defendem que a indústria cria necessidades de consumo para a sociedade massiva e esta de forma 
passiva acaba por alimentar essa indústria the dando cada vez mais lucro. E a Copa do Mundo de Futebol é um exemplo disso, pois a passa tratar, mesmo que de forma implícita, o esporte como um meio e não mais o fim, ou seja, a atividade fim da Copa do Mundo que é melhorar o nível da modalidade futebol pelo planeta, fomentar a prática do esporte, conscientizar uma vida mais saudável acaba sendo engolida pelo consumo paralelo grandes marcas.

Esse excesso de informação a ser consumida reforça cada vez mais o posicionamento acrítico no seio da sociedade, aumentando cada vez mais o número de consumidores alienados. Então cabe a escola realizar esse papel de mediação, esclarecendo a informações que incentivam a prática do consumo.

Ainda no período de observação das aulas percebemos outro elemento que nos chamou bastante atenção. Foi que mesmo a professora fazendo equipes mistas nas aulas de futebol as alunas não se sentiam à vontade na realização das atividades, principalmente, no jogo propriamente dito, razões foram muitas evidenciadas nas próprias falas dos discentes.

“... Não adianta a professora misturar a turma, se os meninos nunca passam a bola só querem que a gente passe pra eles... (ALUNO K)

“... Essas meninas deviam jogar na outra quadra... Estão atrapalhando o nosso tempo aqui” (ALUNO J)

“A gente nem vê jogo de mulher na televisão ... Aí fica até ruim de aprender...Não temos inspiração” (ALUNO U)

Analisando os discursos acima podemos inferir que não adianta elaborar as atividades de forma mista se o discurso enraizado na sociedade/escola alimenta tal discriminação. É necessário problematizar determinados discursos presentes na sociedade. Por que a prática do futebol pelas mulheres não tem o mesmo 
reconhecimento que a prática realizada pelo público masculino?

Partindo de uma análise conceitual, entendemos que o futebol feminino é diferente do futebol de mulheres. O futebol feminino denota um jogar diferente, "romântico" e que leva em consideração as diferentes experiências motoras das praticantes, longe da exigência de habilidades específicas que se assemelham a prática do futebol veiculada na grande mídia. Por outro lado, o futebol de mulheres, é aquele que necessita de um gesto motor mais apurado, habilidades bem específicas, posições táticas bem definidas, ou seja, se aproxima muito do esporte que a mídia costuma transmitir.

Porém, o futebol de mulheres ainda não conseguiu o destaque do futebol de homens. Por que isso acontece? Essas são indagações que devem ser esclarecidas nas aulas de Educação Física, pois esta disciplina é a única que aborda no âmbito escolar os elementos da cultura corporal de movimento, e como o futebol é um grande representante dessa categoria não pode ficar distante do debate.

Retomando aos discursos dos alunos, podemos perceber por meio da ótica da Análise do Discurso (AD), que o sujeito é atravessado tanto pela ideologia quanto pelo inconsciente, sem perceber os alunos reforçam a ideia que existem esportes para mulheres e outros para homens. Esse entendimento é internalizado por parte dos alunos, pois os mesmos comungam da mesma formação discursiva que estão inscritos. Neste sentido, os sujeitos encontram-se interpelados pela ideologia, pois os seus discursos são formados pelas suas experiências anteriores e por isso reproduzem ideias enraizadas na sociedade. 


\section{SEGUNDO TEMPO}

Nesse capítulo que denominamos "Segundo Tempo" partimos da experiência que tivemos a parti de uma diferente estratégia que foi o grupo de discussão que realizamos com a turma acima escolhida. Antes de iniciarmos a aula com a metodologia propriamente dita, solicitamos aos alunos que pesquisassem matérias em revistas, jornais, na internet que tivesse como assunto principal a Copa do Mundo de Futebol de 2014 e estabelecemos uma data para que essa pesquisa fosse explorada na sala de aula.

Vale ressaltar que mesmo os alunos já acostumados com a minha presença no dia em que marcamos a atividade pouquíssimos alunos participaram efetivamente da aula, percebemos que os alunos até estavam munidos de materiais para a discussão, porém notamos que a timidez e a pouca vivência com o debate fez com que a atividade não tivesse tanto elemento a ser explorado.

Porém, mesmo assim utilizamos de nossa experiência para que os alunos pudessem externar as suas ideias e colhermos matérias/discursos para uma posterior análise. Iniciamos o trabalho do grupo de discussão explicando o que era essa proposta de metodologia, falamos também como seria a participação dos alunos, enfatizamos que a pesquisa realizada por eles iria facilitar na hora de fazer as suas considerações. Depois de ter tirado todas as dúvidas dos alunos partimos para a apresentação das matérias realizadas pelo Programa Globo Esporte/ Rj pós jogo da seleção brasileira na Copa do Mundo de Futebol 2014, que justificamos a escolha nas decisões metodológicas do trabalho.

A metodologia do grupo de discussão foi trabalhada da seguinte forma. A turma foi dividida quatro grupos, três grupos com onze alunos e um grupo de 
doze e para cada grupo foi marcado uma data para a realização do trabalho. $\mathrm{O}$ tempo destinado para cada encontro foi de uma hora e trinta minutos para então iniciarmos a pesquisa por meio das discussões estabelecidas. Desta forma, combinamos algumas regras básicas. Determinamos que cada aluno poderia se manifestar quantas vezes quisesse e que cada comentário feito por eles teria o tempo máximo de quatro minutos. Tudo isso, com o intuito dos alunos perceberem a importância do conteúdo futebol e que existem outras maneiras de ser trabalhado na escola, pois necessitamos enriquecer nossa singularidade, não basta entender de regras, táticas e técnicas, é necessário avançar em tais questões: por que o jogador de futebol coloca o nome dos seus familiares na chuteira? Como os jogadores utilizam as redes sociais? O que leva um clube de futebol pagar grandes salários?

Acreditamos que toda essa análise que foi feita por meio de conversas informais e no grupo de discussão sobre os assuntos relacionados à Copa fez com que os alunos se percebessem na relação entre TV, futebol e o seu cotidiano. Esses relatos e discussões nos fazem perceber a importância das mediações nos processos de recepção, pois, caso esse papel não seja desempenhado de forma satisfatória, os nossos alunos não se tornarão sujeitos críticos /emancipados e continuarão reproduzindo os discursos dominantes.

Olhar para a dimensão esportiva conceituá-la enquanto fenômeno cultural implica em compreender não apenas sua condição atual, mas, sua evolução e suas estreitas relações com fenômenos de ordem política, social, econômica e cultural existentes nas sociedades modernas. Por essa razão, o futebol, pode ser entendido como um fenômeno com possibilidade de exercer influências nos cotidianos dos indivíduos. Nesse sentido, não se pode almejar estudar esse fenômeno, sem adotarmos a perspectiva de que a sociedade contemporânea e a 
mídia estão interligadas.

Partimos do pressuposto que esse estudo marca um determinado momento na história da Educação Física, pois investigamos o modo através dos quais, os alunos, em seu cotidiano, estabelecem suas relações com as mídias, em especial a TV, e produzem sentido a partir da sua discursividade. Buscamos problematizar o discurso dos alunos a parti das dos vídeos exibidos. Diante de inúmeras colocações elegemos as ideias que se apresentaram mais freqüentes nos discursos dos alunos. Vale destacar que o campo de pesquisa nos revelou novas situações que de certa forma escaparam do nosso arcabouço teórico, o que não nos impede de problematizar essas questões a partir de novas estratégias de análise.

“A Copa vai gerou mais emprego... É só olhar as cidades sedes como ta cheio de turistas, se têm turistas têm empregos (...)” (Aluno D)

“Com a vinda da Copa o Brasil ficou mais respeitado no mundo, antes as Copas eram só no exterior agora ta aqui e vamos aproveitar e ser campeões (...) “(Aluno E)

"O povo fala que o dinheiro era pra ter investido em escola, hospitais e na segurança... Será se não tivéssemos Copa esse dinheiro iria para esses setores? Antes de ter Copa ninguém falava em aumentar o dinheiro para a saúde e nem para a educação." (Aluno F)

A utilização da recepção midiática por parte dos discursos dos alunos como objeto de análise, nos dá plena possibilidade à nossa pesquisa de a partir da materialidade presente nos discursos observados, encontrar vestígios de um confronto de forças que está muito além do enunciado, que centra seus embates no seio da sociedade. 
Sendo assim, o discurso oficial e conservador sobre a Copa do Mundo gerou eco na fala dos estudantes, estes sem ao menos notar acabaram incorporando a ideologia dominante em seus discursos.

A justificativa para tal fato ocorre porque vivemos num tempo onde a superficialidade das informações e a rapidez com que são produzidas e divulgadas colaboram para que nos tornemos acomodados diante do que é exposto, muitas vezes, fantasiado como uma verdade absoluta.

É inegável, que na sociedade atual, as novas tecnologias de produção, reprodução e difusão de informações e conhecimentos, como televisão, faz parte da inteligibilidade e sensibilidade dos jovens. Na pressa, muitas são as pessoas que se informam pela mídia televisiva diariamente, e para qual o texto escrito, mais que um desafio é antes de tudo uma dificuldade intelectual. Dessa maneira, pouco contato há com a escrita, muito contato há com conteúdos de pouca dificuldade intelectual, com a simplificação da informação e a legitimação do poder dominante, político e econômico.

A classe dominante tende a conferir ao signo ideológico um caráter intangível e acima das diferenças de classe, a fim de abafar ou ocultar a luta dos índices sociais de valor que aí se trava, a fim de tornar o signo monovalente (...) Nas condições habituais da vida social, esta oculta em todo signo ideológico não se mostra à descoberta (BAKHTIN, 2002, p. 47)

Então, as ideologias tornam-se significações/construções da realidade que são edificadas em várias dimensões das formas/sentidos das práticas discursivas e que contribuem para a produção, a reprodução ou a transformação das relações de dominação. Por isso, o discurso é mais o lugar da reprodução que o da criação, assim como uma formação ideológica impõe o que pensar, uma formação discursiva determina o que dizer. 
“Colocaram muita fé em Neymar ... encheram a bola dele acharam que ele seria o cara da Copa como foi Romário e Ronaldo no passado” (ALUNO O)

"O Brasil há anos não produz craques... Jogadores decisivos" (ALUNO R)

Nesses discursos os alunos deixam claro que eles já tiveram outras experiências discursivas acerca dos grandes craques nacionais que através de suas habilidades podem vencer, até mesmo "sozinhos" qualquer seleção.

Eles usam jogadores que tiveram um passado glorioso pra justificar o fracasso da seleção. Dessa forma, a noção de memória discursiva fica evidenciada no discurso do aluno, pois de acordo com Gregolin (2001) todo discurso produz sentido a partir de outro discurso já cristalizado na sociedade. Então podemos inferir que a memória discursiva é sempre acionada no momento de legitimação de uma opinião e que muitas vezes acaba produzindo a homogeneidade discursiva naturalizando assim a ideologia subjacente. Dessa maneira, os discursos vão sendo armazenados ao longo da história para em um dado momento se tornarem materializados constituindo assim o saber discursivo que é fruto da interação entre a língua e a história.

Os dados não têm memória, são os fatos que nos conduzem à memória lingüística. Nos fatos temos a historicidade. Observar os fatos de linguagem vem a ser considerá-los em sua historicidade, enquanto eles representam um lugar de entrada na memória da linguagem, sua sistematicidade, seu modo de funcionamento. Em suma, olharmos o texto como fato,e não como um dado, é observarmos como ele, enquanto objeto simbólico, funciona (ORLAND, 2001, p. 58).

"Eu falo o que penso a seleção brasileira era uma seleção fraca todo mundo sabia, só o Felipão que não ... Ninguém me influenciou na minha opinião, só um louco não via isso... ( ALUNO H) 
"Os principais jornalistas já apontavam pela Neymar dependência... Foi só ele sair ... acabou tudo" (ALUNO P)

Nesse discurso o aluno cria a ilusão que aquela idéia é sua, é autêntica, é inédita. Ele traz em seu discurso o tom da auto-suficiência, ou seja, ele esquece que o sujeito não é a fonte absoluta do significado, do sentido, não é a origem, pois ele se constitui por falas de outros sujeitos. Assim, o sujeito é resultante da interação de várias vozes, da relação com o sócio-ideológico, portanto tem caráter heterogêneo (GUERRA, 2009).

Pêcheux (1996), ao abordar a teoria do esquecimento, destaca que o sujeito se coloca como origem de tudo o que diz. Sendo assim, o sujeito, de modo inconsciente acredita que ele é o criador absoluto do discurso. Na verdade, o autor do discurso seleciona determinadas palavras (ideias) em detrimento de outras para que a sua mensagem tenha sentido e significado num dado momento histórico. Porém, esse sentido e significados não são fixos dependem sofrem variações à medida que são interpretados.

No segundo discurso, o aluno encontra-se alicerçado pelo discurso do especialista. Pois como apontamos, na pressa pela informação, o texto televisivo leva vantagem sobre o texto impresso. Com base no discurso do outro, o sujeito cria a ilusão de ser a fonte ou origem do discurso, passando assim a reproduzir ideologias, pois pra Análise do Discurso o sujeito é essencialmente ideológico e histórico, pois está inserido num determinado lugar e tempo. Com isso, ele vai posicionar o seu discurso em relação aos discursos do outro, estando inserido num tempo e espaço socialmente situados. Betti (1998) denomina esse discurso que nasce a partir de outras vozes que tem o objetivo de informar, explicar e até mesmo prever de "Falação", para o autor a "Falação" é o que sustenta o esporte no Brasil, principalmente, o futebol, por ter maior destaque nas grades de 
programação. São especialistas do mundo futebol jornalistas, cronistas, exjogadores que exploram todos as aspectos do mundo do futebol criam e analisam as notícias relacionadas a esse esporte que seguramente se tornarão pauta de debates dos amantes dessa modalidade.

"O Brasil perdeu a Copa pra ele mesmo "Não podia deixar escapar aqui dentro. Foi vacilo mesmo. (ALUNO V)

"O Brasil passou vergonha. Deu vexame. Afundaram o pais mais ainda. (ALUNOT)

No primeiro discurso percebemos que o aluno, utilizou de eufemismo para justificar a derrota da seleção nacional. Para ele, ninguém teria chance de vencer o Brasil, a não ser ele mesmo. Porém, no segundo discurso o aluno utilizou palavras mais fortes para externar sua indignação com a derrota da seleção brasileira. Nesse sentido, podemos analisar que o mesmo fato pode ter diferentes interpretações e somente um leitor atento pode detectar esses nuances que ocorrem nos fenômenos discursivos.

Esse fenômeno é o que Authier-Revuz (1990) chama de heterogeneidade discursiva, onde diferentes vozes se apresentam acerca de um determinado assunto e em cada uma dela está inserida sua ideologia. Sendo assim, o sujeito a todo o momento retoma outros discursos e este sujeito não percebe sua incompletude, buscando no outro as informações que são de seu interesse. Então, o discurso não pode ser concebido fora do sujeito e nem este fora da ideologia, uma vez que esta o constitui. Essa orientação teórica defende a tese de que a linguagem possui uma relação com a exterioridade, esta entendida não como algo fora da linguagem, mas como condições de produção do discurso. Com base nessa relação da linguagem com a exterioridade, a Análise do Discurso recusa as 
concepções de linguagem que a reduzem ora como expressão do pensamento, ora como instrumento de comunicação. A linguagem é entendida como ação, transformação, como um trabalho simbólico em "que tomar a palavra é um ato social com todas as suas implicações, conflitos, reconhecimentos, relações de poder, constituição de identidade etc.” (ORLANDI, 2001, p.17).

Segundo Guerra (2009), a relação entra linguagem como interação é um modo de produção social, que não é neutra nem natural, sendo o local privilegiado da manifestação da ideologia, isto é, das formações ideológicas que estão diretamente ligadas aos sujeitos. Podemos dizer que não se parte da ideologia para o sentido, mas procura-se compreender os efeitos de sentido a partir do fato de que é no discurso que se configura a relação da língua com a ideologia. Sendo assim, o discurso é o ponto de articulação dos processos ideológicos e dos fenômenos lingüísticos. 


\section{CONCLUSÃO}

A pesquisa nos fez perceber que pavimentando uma estrada pouco trafegada podemos abrir um "novo" caminho a ser debatido e problematizado no campo da Educação Física. O presente trabalho partiu de uma realidade escolar que foi interpretada a partir do olhar de jovens escolares sobre a Copa do Mundo de 2014.

Constatamos que os alunos têm certa noção de que a mídia atua como veiculo que defende interesses daqueles que a financiam, por isso acreditam que têm o nível de criticidade satisfatório para não se tornarem influenciados pelos veículos midiáticos.

Por outro lado, vimos que interpretando os discursos dos alunos pudemos perceber que existem elementos que denunciam que o discurso midiático encontra-se impregnado nas falas dos discentes. Entendemos essa constatação não como um defeito por parte dos alunos, o que salientamos é que a escola enquanto instituição formadora deva assumir esse papel de mediação, ou seja, a escola deve se aproximar mais do seu aluno e saber como ele se informa e o que consome no seu cotidiano.

Os alunos percebem a importância da educação física na escola, todavia de forma bem superficial, para eles a disciplina serve para "se movimentar" enquanto outras servem para apreender com uma exigência intelectual bem maior.

Isso acontece porque historicamente os professores de educação física são caracterizados pelo fazer em vez do conhecer, apesar do vasto conhecimento que vem sendo produzido no que diz respeito à metodologia das aulas de educação 
física, no dia-a-dia o cenário não mudou, as práticas tecnicistas do fazer por fazer descontextualizadas ainda imperam, sendo assim qualquer experiência fora da metodologia tradicional sofre grande resistência.

Sendo assim, a escola e posteriormente os professores de educação física devem ter uma maior acuidade sobre os elementos da cultura corporal de movimento que são veiculados na mídia, pois esses elementos servirão de objetos a serem problematizados nas aulas de educação física tornando o conteúdo trabalhado mais enriquecedor.

Destacamos que a mediação foi em maior intensidade atribuída à escola e a disciplina de educação física, pois nos discursos analisados pelos alunos não encontramos elementos que evidenciavam uma grande influência de outros tipos de mediação como a família, a igreja, predominantemente encontramos na voz dos alunos o discurso da mídia.

Neste sentido, análise do discurso representa uma nova abordagem do estudo que vai além da linearidade, relacionando enunciado e enunciação como elementos fundamentais da produção de sentido. A abordagem interna do discurso leva-nos a reconhecer os mecanismos e regras de engendramento do discurso e a análise externa, a reconstituição do contexto sócio-histórico, permite-nos entender a construção dos sentidos de cada abordagem.

Pensar a mídia sob o enfoque teórico e metodológico da Análise do Discurso é uma tentativa de compreender o que há por detrás dos enunciados, para que se investiguem as ideologias que perpassam os seus discursos, os diálogos que mantém com os outros fatos, as figurativizações que existem nos meios de comunicação, a focalização em torno dos fatos, o nível de (im) parcialidade, etc. 
Ao analisar o discurso dos alunos, podemos inferir que o sentido dos discurso por meio da sua materialidade, ou seja, verificando as marcas que regem a construção do sentido dentro de um determinado contexto e que nos guiam a uma interpretação da realidade, compreendemos que o discurso midiático, seja ele qual for a predominância estilística quanto ao seu gênero, carrega consigo marcas de representação de um discurso que confere uma visão de mundo, um enquadramento, uma forma que "quase" sempre está submetida a relações de poder dentro e fora do espaço midiático, pois o discurso, muitas vezes, se torna interpelado pelas instâncias do poder.

Os discursos dos alunos oferecem pontos de vista, sugestões e mesmo indiretamente, respostas. Assim, a atividade midiática é uma das principais responsáveis por tornar pública grande parte das informações e por trazer para a discussão os acontecimentos e idéias que possivelmente farão parte da agenda do público. Por isso, tentamos demonstrar, no decorrer desse trabalho, que as relações entre mídia e futebol não podem ser dadas simplesmente com a afirmação da manipulação dos meios e da passividade do leitor.

Sendo assim, acreditamos que, em meio ao processo desenvolvido pela pesquisa, conseguimos de alguma forma, contribuir na busca de um olhar mais crítico acerca do futebol nas aulas de educação física e esperamos com bastante otimismo que os alunos consigam perceber através do seu olhar crítico as estratégias de manipulações feitas pela mídia. Não queremos dá receitas de como os alunos vão buscar essa solidez crítica, mas torcemos sim que eles filtrem ao seu modo as informações que nos rodeiam.

Neste mesmo viés, este estudo contribui para a Educação Física se aceitarmos o futebol como fenômeno social, tema da cultura corporal, onde precisam ser questionado suas normas, suas condições de adaptação à realidade 
social e cultura, pois o futebol, quando analisado dentro de uma perspectiva social, acaba por tornar-se mais que uma ferramenta de aprendizagem que leva a reflexão para além dos campos de futebol.

Nesse sentido, cabe ao leitor perceber que a produção da informação feita pela mídia constitui representação da realidade que segue interesses e objetivos de atores internos e externos a este espaço e que vão influenciar diretamente na construção de uma notícia. Dessa maneira, devemos compreender o discurso midiático como mediação e não como único determinante ideológico, pois eles se referem muito mais à manutenção da ordem estabelecida socialmente do que a algum tipo de mudança dessa ordem pré-estabelecida.

Nas análises que fizemos e, observamos que os alunos, mesmo que de forma involuntária optaram por um posicionamento ideológico que melhor convinha a partir de estratégias discursivas. Vale ressaltar que não podemos generalizar que todos os alunos ainda precisam de uma criticidade mais aguçada, pois partimos de um grupo de alunos em um dado contexto sociocultural.

A análise que propusemos a fazer é apenas uma forma de entender o discurso enquanto prática de uma sociedade. É uma visão e como tal não uma verdade absoluta. É um rascunho de uma possível realidade. É apenas uma maneira de refletir sobre a educação física. 


\section{REFERÊNCIAS}

ADORNO, Theodor W.; HORKHEIMER, Marx. Dialética do esclarecimento: fragmentos filosófico. Rio de Janeiro: Jorge Zahar Editor, 1985. Tradução Guido Antônio de Almeida

ALTHUSSER, L. Aparelhos Ideológicos do Estado. Rio de Janeiro: Graal, 2001.

ANTUNES, Sheila Espíndola. O país do futebol "na copa do mundo": estudo de recepção ao discurso midiático - esportivo com jovens escolares. Dissertação (Mestrado em Educação Física). PPGEF/UFSC. Florianópolis: 2007.

ATLAS do Desenvolvimento Humano no Brasil. Rio de Janeiro, PNUD, IPEA, Fundação João Pinheiro, 2003. IDH, 2014.

AUTHIER-REVUZ, J. Heterogeneidade(s) Enunciativa(s). Cadernos de Estudos Lingüísticos, Campinas, SP, n. 19, p. 25-42, 1990.

BAKHTIN, M. Estética da criação verbal. São Paulo: Martins Fontes, 2002.

BAUMAN, Zygmunt. Identidade. Rio de Janeiro: Jorge Zahar Editor, 2005. Tradução de Carlos Alberto Medeiros.

BECKER, Howard Saul. Métodos de pesquisa em ciências sociais. 2. ed. São Paulo: Hucitec, 1994.

BELLONI, Maria Luiza. O que é mídia-educação. Polêmicas do nosso tempo. 2 ed. Campinas: Autores Associados, 2007.

BELLOS, Alex. Futebol em campo. Rio de Janeiro: Ed. Jorge Zahar, 2003.

BENJAMIN, Walter. "A obra de arte na era de sua reprodutibilidade técnica”. São Paulo, 1983. Abril, p. 165-196 (col. “Os Pensadores”).

BETTI, M., Esporte na Mídia ou esporte da Mídia? In: Revista Motrivivência, Ano XII, nº 17, Educação Física, Esporte, Lazer e Mídia (1) p. 107 - 111, set./2001. Editora da UFSC. Florianópolis, SC. 
BETTI, Mauro. Janela de vidro: esporte, televisão, educação física. Campinas: Papirus, 1998.

BOGDAN, Robert; BIKLEN, Sari. Investigação qualitativa em educação. Uma introdução à teoria e aos métodos. Portugal: Porto Editora, 1994. Tradutores: Maria João Alvarez, Sara Bahia dos Santos e Telmo Mourinho Baptista.

BRACHT, V. Esporte na escola e esporte de rendimento. Movimento, Porto Alegre, v. 06, n.12, p. XIV-XXIV, 2000.

BRANDÃO, Helena H. Nagamine. Introdução à análise do discurso. 7. ed. Campinas, SP: UNICAMP, 1998a.

BUCKINGHAM, D. Children talking television: the making of television literacy. London: Falmer, 1993.

CALDAS, G. O discurso político na mídia: eleições presidenciais no Brasil em 2002. In: CONGRESSO BRASILEIRO DE CIÊNCIAS DA COMUNICAÇÃO - INTERCOM. 26., 2003, Núcleo de Pesquisa de Jornalismo. Anais... Belo Horizonte: Vertent Soluções Interativas, 2003.

CHAUÍ, Marilena. O que é ideologia. 2. ed. São Paulo: Brasiliense, 2006. (Coleção primeiros passos).

COURTINE, J. J. O Chapéu de Clémentis. Observações sobre a memória e o esquecimento na enunciação do discurso político. In: INDURKY, Freda. (Org.). Os múltiplos territórios da análise do discurso. Porto Alegre: Sagra Luzzato, 1999.

DA MATTA, Roberto ET AL. Universidade do futebol: esporte e sociedade brasileira. Rio de Janeiro. Pinakotheka, 1982.

Daólio, Jocimar. Cultura: educação física e futebol. Campinas. Ed. da Unicamp, 1997.

DEMO, Pedro. Questões para a Teleducação. Petrópolis, RJ: Vozes, 1998.

DUMAZEDIER, Jofre. Democratização do esporte? In: Cadernos de Lazer, SESC/SP, n. 4, maio, 1979. 
ECO, Umberto. Apocalípticos e integrados. São Paulo: Perspectiva, 1993. Os limites da Interpretação. 2. ed. São Paulo Perspectiva, 2004.

FADUL, A.M. Indústria cultural e comunicação de massa. Disponível em: <www.crmariocovas. sp.gov.br/pdf/c_ideias_17_053_a_059.pdf>. Acesso em: 05 out. 2013.

FAIRCLOUGH, N. Discurso e Mudança Social. Brasília: Editora Universidade de Brasília, 2001.

FANTIN, Monica. Mídia-educação: conceitos, experiências, diálogos. Florianópolis: Cidade Futura, 2006.

FERNANDES, Cleudemar Alves. Análise do discurso: reflexões introdutórias. 2. ed. São Carlos: Claruz, 2007.

FERRÉS, Joan. Televisão e educação. Porto Alegre: Artes Médicas, 1994.

FIORIN, José Luíz. As astúcias da enunciação. 2. ed. São Paulo: Ática, 1999. . Linguagem e Ideologia. São Paulo: Ática, 2001.

FOUCAULT, Michel. A ordem do discurso. 5. ed. São Paulo: Loyola, 1999.

Freire, Paulo. Pedagogia da autonomia: saberes necessários à pratica educativa. 31. ed. São Paulo: Paz e terra, 2005.

FREITAS, Gustavo da Silva. A seleção Brasileira de Futebol na Copa América de 2007: uma demanda discursiva. In: Revista da Educação Física/UEM, Maringá, v.20, n.4, p.543-554, 2008.

FUENZALLIDA, Valério. EI Televidente Activo. Santiago, CPU, 1999

GADOTTI, Moacir. A escola frente à cultura midiática. In: OROFINO, Maria Izabel. Mídias e mediação escolar: pedagogia dos meios, participação e visibilidade. São Paulo: Cortez: Instituto Paulo Freire, 2005. p.15-94. (Guia da Escola Cidadã: v.12) 
GIL, Antonio Carlos. Método e técnicas de pesquisa social. 4. ed.São Paulo: Atlas S. A, 1995.

GODOY, A. S. Introdução à pesquisa qualitativa e suas possibilidades. Revista de Administração de Empresas (RAE). V. 35, n. 2; Mar - Abr 1995. p.57-62

GOELLNER, S.V. Pesquisa qualitativa na educação física brasileira: marco teórico e modos de usar. Revista da Educação Física/UEM, Maringá, v. 21, p. 53-82, 2010.

GONDIM, S.M.G. Grupos focais como técnica de investigação qualitativa: desafios metodológicos. Disponível em:

<sites.ffclrp.usp.br/paideia/artigos/24/03.doc>. Acesso em: 5 out. 2013.

GREGOLIN, M. R. (Org.). Análise do discurso em torno dos sentidos. São Paulo: Cultura Acadêmica, 2001.

GUERRA,Vânia Maria Lescano. A análise do discurso de linha francesa e a pesquisa nas ciências humanas. An. Sciencult, v.1, n.1, Paranaíba, 2009.

Hall S. A identidade cultural na pós-modernidade. 10. ed. Rio de janeiro: dp\&a, 2006.

HELAL, Ronaldo. O que é sociologia do esporte. São Paulo: Brasiliense, 1999 (coleção prime).

JACKS, Nilda. Pesquisa de Recepção e Cultura Regional. IN: SOUSA, Mauro W. de. (Org.) Sujeito, o lado oculto do receptor. São Paulo: Brasiliense, 1995. Tradução e transcrição Sílvia Cristina Dotta e Kiel Pimenta.

Querência: Cultura Regional como Mediação Simbólica - um estudo de recepção. Porto Alegre: Ed. Universidade/UFRGS, 1999.

KELLNER, Douglas. A cultura da mídia. Bauru, SP: Edusc, 2001.

KUNZ, E. Transformação didático-pedagógica do esporte. Ijuí: Unijuí, 1994

LISBOA, Mariana Mendonça. Jogos Pan-Americanos Rio/2007 e a cobertura do Jornal Nacional: ênfases e representações veiculadas. In: IV Congresso de Sulbrasileiro de Ciências do Esporte. Faxinal de Céu/ PR, 2008. 
LOPES, Denilson. O homem que amava rapazes e outros ensaios. Rio de Janeiro: Aeroplano, 2002.

MAINGUENEAU, D. Novas tendências em análise do discurso. 3. ed. Campinas: Pontes, 1997.

MARTIN-BARBERO, Jesús. Dos meios às mediações: comunicação, cultura e hegemonia. Rio de Janeiro: Ed. UFRJ, 1997.

MASCARENHAS, Fernando; et al. O bloco olímpico: Estado, organização esportiva e mercado na configuração da agenda Rio 2016. [S.I.: s.n.], 2011.

MEDEIROS, Ana Gabriela Alves. O futebol feminino no discurso televisivo. IN: Revista Brasileira de Ciências do Esporte, Florianópolis, v.34, n.1, p.1851996, jan/mar.2012.

MENDES, Diego de Sousa. Desvendando a janela de vidro: relato de uma experiência escolar mídia-educação e Educação Física. In: Revista Brasileira de ciências do esporte, Campinas, v.30,n.3, p.79-94, maio, 2008.

MEZZAROBA, Cristiano. Os Jogos Pan-Americanos Rio/2007 e o agendamento midiático-esportivo: um estudo de recepção com escolares. Dissertação (Mestrado em Educação Física). PPGEF/UFSC. Florianópolis: 2011.

MILAN, B. O país da bola. São Paulo: Record, 1998.

MINAYO, Maria Cecília de Souza. O desafio do Conhecimento: Pesquisa Qualitativa em Saúde. 9 ed. São Paulo: Hucitec, 1994.

MORAN, J. M. Leituras dos Meios de comunicação. São Paulo: Rancast, 1993.

MORIN, Edgar. Cultura de massa no século XX: o espírito do tempo-V.INeurose. Rio de Janeiro: Forense Universitária, 1984.

NAPOLITANO, M. Como usar a televisão na sala de aula. São Paulo: Contexto, 2007.

ORLANDI, Eni. Análise do Discurso: princípios e procedimentos. 3. ed. Campinas: Pontes, 2001. 
OROFINO, Maria Isabel. Mídias e mediações escolar: pedagogia dos meios, participação e visibilidade. São Paulo: Cortez: Instituto Paulo Freie, 2005.

OROZCO. Guillermo G. Professores e meios de comunicação: desafios, estereótipos. Comunicação e Educação, n.10, p. 57-68, set.-dez., 1997.

PECENIN, Marcelo Fila. Discurso e do sobre o futebol brasileiro: o poder midiático na regulação das identidades Dissertação (Mestrado) 184f. -Universidade Federal de São Carlos, UFSCar, 2008.

PÊCHEUX, Michel. O mecanismo da (des)construção ideológica. In. ZIZEK, S. (Org.). Um mapa da ideologia. Rio de Janeiro: Contraponto, 1996.

PIRES, Giovani D.L. Educação física e o discurso midiático: abordagem crítico-emancipatória. Ijuí/RS: UNIJUÍ, 2006 (Coleção Educação Física).

PIRES, G. L. P. A Educação física e o discurso midiático: abordagem críticoemancipatória em pesquisa-ação no ensino de graduação: subsídios para a saúde? 2000. 228 f. Tese (Doutorado em Educação Física) - Faculdade de Educação Física, Universidade Estadual de Campinas, Campinas, 2000.

POZZI, Luiz Fernando. Reflexões sobre o futebol empresa no Brasil. In: COSTA, Marcia Regina; et al. (Orgs.). Futebol: espetáculo do século. São Paulo: Musa, 1999.

RIGO, Luiz Carlos. Discursos de uma derrota: um estudo da produção discursiva sobre a eliminação da seleção brasileira na Copa do Mundo de 2006. In: Revista Brasileira de Ciências Dom Esporte, Campinas, v.30, n.3, p.111-125, maio 2009.

SALGADO, Raquel Gonçaives. Da recepção à produção de mídia: as crianças, a cultura midiática e a educação. In: Revista ALCEU- V.7, N.13, P.165-181. JUL - DEZ, 2006

SANTAELLA, Lucia. Cultura das mídias. 4. ed. São Paulo: Experimento, 1992. 
SANTOS, Guilherme Ferreira. O discurso midiático dos jogos pan - americanos Rio/2007 e candidatura aos jogos de 2016: O “Trampolin” do Brasil. Universidade Federal de Viçosa. Coleção Pesquisa em Educação Física - vol.8, $\mathrm{n}^{\mathrm{o}}, 2009$.

SANTOS, Alan Lagoa; MEZZAROBA, Cristiano. Esporte e mídia: um estudo de recepção ao discurso midiático-esportivo e algumas implicações na Escola. Revista da Unifebe $\mathrm{n}^{\circ} 10$. Disponivel em:

$<$ http://periodicos.unifebe.edu.br/index.php/revistaeletronicadaunifebe/article/vie wFile/17/15>. Acesso em: 18 jun. 2015.

SETTON, Maria da Graça. Mídia e Educação. São Paulo: Contexto, 2011

SILVA, Maria Ozanira da Silva (Org.). Pesquisa Avaliativa: aspectos teóricos metodológicos. São Paulo: Veras; São Luís: GAEPP, 2008.

SILVERSTONE, Roger. Por que estudar a mídia? SP: Loyola, 2002.

SODRÉ, Muniz. O discurso da nova barbárie. In: MORAES, Dênis de (org.). Globalização, mídia e cultura contemporânea. Campo Grande: Letra Livre, 1997.

SOUZA JÚNIOR, M. O saber e o fazer pedagógicos: a Educação Física como componente curricular...? isso é história? Recife: EDUPE. 1999.

THOMPSON, John. A Mídia e a Modernidade: uma teoria social da mídia. Petrópolis: Vozes, 1998.

Ideologia e cultura moderna: teoria social crítica na era dos meios de comunicação de massa. Petrópolis: Vozes, 1995.

TRIVIÑOS, A. Introdução à pesquisa em ciências sociais: a pesquisa qualitativa em educação. São Paulo: Atlas, 1987.

ZANCHETTA JUNIOR, Juvenal. Estudos sobre recepção midiátia no Brasil. Revista Scielo/Unicamp. Campinas - SP, 2006. 
APÊNDICES 
APÊNDICE A - Questionário

\author{
Universidade de Brasília \\ Mestrado em Educação Física \\ Pesquisador: Ywry Crystiano da Silva Magalhães
}

Questionário

Identificação:

Sexo: Idade:

Período de estudo: Matutino ( ) Vespertino ( )

1. Gosta de assistir televisão? Sim ( ) Não ( )

2. Qual a frequiência?

3. Possui TV por assinatura? Sim ( ) Não ( )

4. Quantos aparelhos de televisão há em sua casa?

5. Você possui uma televisão em seu quarto? Sim ( ) Não ( )

6. No geral, quanto tempo por dia você acha que assiste à televisão?

( ) menos de 1 hora/dia

( ) entre 1 a 2 horas/dia

( ) mais que 2 horas por dia. 
7. Quais os principais programas que você assiste na televisão?

8. Você se interessa por programas esportivos? Se sim, qual? Sim ( ) Não ( )

9. Enquanto assiste aos programas, o que lhe chama mais atenção?

Comentários:

10. Qual tipo de informação você busca nestes programas?

11. Você acha que as informações que são veiculadas nesses programas influenciam nos seus padrões de comportamento e de consumo? Se sim, por quê?

12. Com quem você tem o hábito de conversar sobre os assuntos que lhe Interessam?

13. Você acompanhou a Copa do Mundo? Se sim, por qual emissora?

14. Você acha que as informações transmitidas por essa emissora sobre a Copa do Mundo, e mais precisamente sobre o futebol geraram expectativas para as aulas de Educação Física? Se sim, por quê? 
15. Existe algum outro meio de comunicação que você costuma de acessar? Qual (is)?

16. Foi feito algum trabalho na escola tematizando a copa do mundo?

17. Como foi sua participação? 
APÊNDICE B - Termo de Consentimento Livre e Esclarecido - TCLE

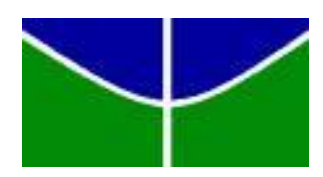

TERMO DE CONSENTIMENTO LIVRE E ESCLARECIDO - TCLE

\section{UNIVERSIDADE DE BRASÍLIA \\ FACULDADE DE EDUCAÇÃO FÍSICA \\ PROGRAMA DE PÓS GRADUAÇÃOSTRICTU SENSU EM EDUCAÇÃO FÍSICA}

\section{TERMO DE CONSENTIMENTO LIVRE E ESCLARECIDO DE PARTICIPAÇÃO NA PESQUISA}

Você está sendo convidado (a) para participar, como voluntário, em uma pesquisa. Será garantido o sigilo total da identidade de todos os pesquisados envolvidos neste estudo, lhe assegurando (a) que seu nome não aparecerá, sendo mantido o mais rigoroso sigilo através da omissão total de quaisquer informações que permitam identificá-lo(a). Após ser esclarecido (a) sobre as informações a seguir, no caso de aceitar fazer parte do estudo, assine o documento de consentimento de sua participação, que está em duas vias. Uma delas é sua e a outra é do pesquisador responsável. Em caso de recusa você não será penalizado de forma alguma, bem como se ficar constrangido em responder alguma das perguntas feitas no questionário e grupo focal e terá todo direito de não respondê-la. Em caso de dúvida você pode entrar em contato pessoalmente com o pesquisador através do e-mail: ywry.magalhães@ifma.edu.br, por telefone celular: (8) 81161213 ou procurar a Secretaria de Pós Graduação da Faculdade 
de Educação Física da Universidade de Brasília pelo telefone ( 61)3107-2511.

\section{INFORMAÇÕES SOBRE A PESQUISA:}

Título do Projeto: DE ANTENA LIGADA NA "ATENAS BRASILEIRA": um estudo de recepção midiática em torno da Copa do Mundo de 2014 sob olhares de jovens escolares em São Luís - MA

Orientador: Prof ${ }^{\circ}$. Dr. Alfredo Feres Neto

\section{Descrição da pesquisa:}

Este trabalho teve como objetivo analisar a recepção midiática dos discursos televisivos em torno do futebol por meio dos procedimentos discursivos e interdiscursivos. Nesse sentido, em nosso estudo utilizamos um quadro teórico composto pelos conceitos da Teoria da Análise do Discurso articulados aos estudos de Recepção e da Teoria das Múltiplas Mediações, sob o viés dos Estudos Latino-Americanos. O trabalho de campo será realizado na Escola Cintra em São Luís - MA, em uma turma de $1^{\circ}$ ano do ensino médio. Para conhecermos suas principais mediações e o tratamento dados as mensagens que consomem por meio do discurso televisivo acerca do futebol na Copa do Mundo de 2014 serão mobilizados como procedimentos, instrumentos e técnicas de pesquisa: questionário, grupos focais e observação participante.

\section{Observações importantes:}

A sua participação ocorrerá através de uma tarefa de respostas a um questionário e participação no grupo focal onde será estimulado a opinar sobre materiais jornalísticas a acerca do futebol. Suas respostas serão gravadas em aparelho sonoro que auxiliarão o pesquisador na coleta dos dados. A pesquisa não envolve riscos à saúde, integridade física ou moral daquele que será sujeito da pesquisa. 
Não será fornecido nenhum auxílio financeiro, por parte dos pesquisadores, seja para transporte ou gastos de qualquer outra natureza. A coleta de dados deverá ser autorizada e poderá ser acompanhada por terceiros. O resultado obtido com os dados coletados, bem como possíveis imagens, serão sistematizados e posteriormente divulgado na forma de uma Dissertação de Mestrado, que será apresentada em sessão pública de avaliação disponibilizado para consulta através da Biblioteca Digital de Monografias da UnB. Este projeto foi Aprovado pelo Comitê de Ética em Pesquisa da Faculdade de Ciências da Saúde da Universidade de Brasília. As dúvidas com relação à assinatura do TCLE ou os direitos do sujeito da pesquisa podem ser obtidos através do telefone: (61) 3107 1947 ou do e-mail cepfs@unb.br. 
APÊNDICE C - Termo de Consentimento da Participação na Pesquisa TERMO DE CONSENTIMENTO DA PARTICIPAÇÃO NA PESQUISA

$\mathrm{Eu}$, , $\mathrm{RG}$

aceito participar desta pesquisa para utilização de fins acadêmicos e científicos do conteúdo de resposta ao questionário e no grupo focal para a pesquisa de título: DE ANTENA LIGADA NA “ATENA BRASILEIRA: um estudo de recepção midiática em torno da copa do mundo sob olhares de jovens escolares em São Luís - MA. Fui devidamente esclarecido pelo pesquisador Ywry Crystiano da Silva Mahalhães sobre a pesquisa, os procedimentos nela envolvidos, assim como os seus objetivos e finalidades. Foi-me garantido que poderei desistir de participar em qualquer momento, sem que isto leve à qualquer penalidade. Também fui informado que os dados coletados durante a pesquisa, e também imagens, serão divulgados para fins acadêmicos e científicos, através de um Trabalho de Dissertação (Mestrado em Educação Física) que será apresentado em sessão pública de avaliação e posteriormente disponibilizado para consulta através da Biblioteca Digital de Dissertações da UnB.

Nome / assinatura

Pesquisador Responsável

Nome e assinatura

Brasília, de de 